\title{
Synthesis and Characterization of New Palladium(II) Thiosemicarbazone Complexes and Their Cytotoxic Activity against Various Human Tumor Cell Lines
}

\author{
Wilfredo Hernández, ${ }^{1}$ Juan Paz, ${ }^{1}$ Fernando Carrasco, ${ }^{2}$ \\ Abraham Vaisberg, ${ }^{3}$ Evgenia Spodine, ${ }^{4}$ Jorge Manzur, ${ }^{5}$ Lothar Hennig, ${ }^{6}$ \\ Joachim Sieler, ${ }^{6}$ Steffen Blaurock, ${ }^{6}$ and Lothar Beyer ${ }^{6}$ \\ ${ }^{1}$ Facultad de Ingeniería Industrial, Universidad de Lima, Avenida Javier Prado Este Cuadra 46, \\ Urbanización Monterrico, Lima 33, Peru \\ ${ }^{2}$ Facultad de Ciencias Naturales y Matemática, Universidad Nacional Federico Villarreal, Jr. Río Chepén s/n, \\ El Agustino; Lima, Peru \\ ${ }^{3}$ Laboratorio de Investigación y Desarrollo, Facultad de Ciencias y Filosofía, Universidad Peruana Cayetano Heredia, \\ Avenida Honorio Delgado 430, Urbanización Ingeniería-San Martin de Porras, Lima 31, Peru \\ ${ }^{4}$ Facultad de Ciencias Químicas y Farmacéuticas, Universidad de Chile, CEDENNA, Olivos 1007, Casilla 233, \\ Independencia, 8330492 Santiago, Chile \\ ${ }^{5}$ Facultad de Ciencias Físicas y Matemáticas, Universidad de Chile, CEDENNA, 8370448 Santiago, Chile \\ ${ }^{6}$ Fakultät für Chemie und Mineralogie, Universität Leipzig, Johannisallee 29, 04103 Leipzig, Germany
}

Correspondence should be addressed to Wilfredo Hernández; whernandez79@yahoo.es

Received 9 July 2013; Revised 27 September 2013; Accepted 3 October 2013

Academic Editor: Ian Butler

Copyright (C) 2013 Wilfredo Hernández et al. This is an open access article distributed under the Creative Commons Attribution License, which permits unrestricted use, distribution, and reproduction in any medium, provided the original work is properly cited.

\begin{abstract}
The palladium(II) bis-chelate complexes of the type $\left[\mathrm{Pd}\left(\mathrm{TSC}^{1-5}\right)_{2}\right](6-10)$, with their corresponding ligands 4-phenyl-1-(acetone)thiosemicarbazone, $\operatorname{HTSC}^{1}$ (1), 4-phenyl-1-(2'-chloro-benzaldehyde)-thiosemicarbazone, HTSC ${ }^{2}$ (2), 4-phenyl-1-( $3^{\prime}$-hydroxybenzaldehyde)-thiosemicarbazone, $\operatorname{HTSC}^{3}$ (3), 4-phenyl-1-(2'-naphthaldehyde)-thiosemicarbazone, HTSC ${ }^{4}$ (4), and 4-phenyl1-(1'-nitro-2' -naphthaldehyde)-thiosemicarbazone, $\operatorname{HTSC}^{5}(\mathbf{5})$, were synthesized and characterized by elemental analysis and spectroscopic techniques (IR and ${ }^{1} \mathrm{H}$ - and ${ }^{13} \mathrm{C}$-NMR). The molecular structure of HTSC ${ }^{3}$, HTSC ${ }^{4}$, and $\left[\mathrm{Pd}\left(\mathrm{TSC}^{1}\right)_{2}\right](6)$ have been determined by single crystal X-ray crystallography. Complex 6 shows a square planar geometry with two deprotonated ligands coordinated to $\mathrm{Pd}^{\mathrm{II}}$ through the azomethine nitrogen and thione sulfur atoms in a cis arrangement. The in vitro cytotoxic activity measurements indicate that the palladium(II) complexes $\left(\mathrm{IC}_{50}=0.01-9.87 \mu \mathrm{M}\right)$ exhibited higher antiproliferative activity than their free ligands $\left(\mathrm{IC}_{50}=23.48-70.86\right.$ and $\left.>250 \mu \mathrm{M}\right)$ against different types of human tumor cell lines. Among all the studied palladium(II) complexes, the $\left[\mathrm{Pd}\left(\mathrm{TSC}^{3}\right)_{2}\right](8)$ complex exhibited high antitumor activity on the DU145 prostate carcinoma and K562 chronic myelogenous leukemia cells, with low values of the inhibitory concentration $(0.01$ and $0.02 \mu \mathrm{M}, \mathrm{resp}$.).
\end{abstract}

\section{Introduction}

In recent years, sulfur containing ligands such as dithiocarbamates and thiosemicarbazones and their transition metal complexes have received more attention in the area of medicinal chemistry, due to their pharmacological properties, such as antiviral [1-3], antibacterial [4-7], antifungal [8-10], antiparasitic [11, 12], and antitumor [13-19] activities.
The synthesis of thiosemicarbazones $(\mathrm{R}-\mathrm{CH}=\mathrm{N}-\mathrm{NH}-$ CS-NHR ${ }^{1}$ ) has been developed due to the facility to replace the $\mathrm{R}$ and $\mathrm{R}^{1}$ substituent groups by alkyl, aryl, or heterocyclic derivative and thus leading to a broad spectrum of new bidentate $(\mathrm{N}, \mathrm{S}$ or $\mathrm{N}, \mathrm{N})$ and tridentate $(\mathrm{N}, \mathrm{N}, \mathrm{N}$ or $\mathrm{N}, \mathrm{N}, \mathrm{S})$ and also tetra- and pentadentate ligands, capable of coordinating to metal centres [6,20-22]. 
It has been shown that the $\alpha$-(N)-heterocyclic carbaldehyde thiosemicarbazones act as chelating agents of the transition metals and some of them exhibit antitumor activity by inhibiting the biosynthesis of DNA, possibly by blocking the enzyme ribonucleotide diphosphate reductase [23-25]. On the other hand, the ligand 6-methylpyridine-2-carbaldehyde$\mathrm{N}(4)$-ethylthiosemicarbazone (HmpETSC) and its complexes [ $\left.\mathrm{Zn}(\mathrm{HmpETSC}) \mathrm{Cl}_{2}\right]$ and $[\mathrm{Pd}(\mathrm{mpETSC}) \mathrm{Cl}]$ exhibit antineoplastic activity against colon cancer human cell lines (HCT 116) with $\mathrm{IC}_{50}$ values of $14.59,16.96$, and $20.65 \mu \mathrm{M}$, respectively [26].

In previous articles, we have reported the cytotoxic activity of the ligands derived from benzaldehyde and furaldehyde thiosemicarbazone and their palladium(II) bischelate complexes. In vitro antitumor studies against different human tumor cell lines revealed that these metal complexes $\left(\mathrm{IC}_{50}=0.21-12.46 \mu \mathrm{M}\right)$ were more cytotoxic than their corresponding ligands $\left(\mathrm{IC}_{50}>60 \mu \mathrm{M}\right)$. On the other hand, the platinum(II) tetranuclear, $\left[\mathrm{Pt}_{4} \mathrm{~L}_{4}\right](\mathrm{HL}=4$-phenyl-1benzaldehyde thiosemicarbazone), exhibits higher antiproliferative activity with $\mathrm{IC}_{50}$ values in the range of $0.07-0.12 \mu \mathrm{M}$ [27].

The present work describes the synthesis, characterization, and antitumor activity of palladium(II) bis-chelate complexes of the type $\left[\mathrm{Pd}\left(\mathrm{TSC}^{1-5}\right)_{2}\right](\mathbf{6 - 1 0})$ with the ligands 4-phenyl-1-(acetone)-thiosemicarbazone, $\operatorname{HTSC}^{1}$ (1), 4-phenyl-1-(2'-chloro-benzaldehyde)-thiosemicarbazone, HTSC ${ }^{2}$ (2), 4-phenyl-1-(3'-hydroxy-benzaldehyde)-thiosemicarbazone, $\operatorname{HTSC}^{3}$ (3), 4-phenyl-1-(2'-naphthaldehyde)-thiosemicarbazone, $\operatorname{HTSC}^{4}(\mathbf{4})$, and 4-phenyl-1-(1' -nitro-2' -naphthaldehyde)-thiosemicarbazone, $\operatorname{HTSC}^{5}(5)$.

\section{Experimental}

2.1. Materials and Measurements. Chemicals were reagent grade and were used without further purification. Palladium (II) bis(acetylacetonate), potassium tetrachloropalladate, acetone, 4-phenyl-thiosemicarbazide, o-chloro-benzaldehyde, m-hydroxy-benzaldehyde, naphthaldehyde, and 1-nitro-2naphthaldehyde were purchased from Aldrich. Elemental analyses were determined on a Fisons-Carlo Erba Elemental Microanalyzer. Infrared spectra were recorded as $\mathrm{KBr}$ pellets $\left(4000-400 \mathrm{~cm}^{-1}\right)$ on a Bruker FT-IR IFS 55 Equinox spectrophotometer. The $\mathrm{FAB}(+)$ mass spectra were recorded on a ZAB-HSQ (V.G. Analytical Ltd. Floats Roads, Wythenshawe, Manchester, UK) spectrometer, using 3-nitrobenzyl alcohol as the matrix. NMR spectra were recorded on a Bruker Avance DRX 300 spectrometer in DMSO- $\mathrm{d}_{6}$, operating at 300 and $75.5 \mathrm{MHz}\left({ }^{1} \mathrm{H},{ }^{13} \mathrm{C}\right)$. The chemical shifts were measured in ppm relative to tetramethylsilane $\left(\mathrm{SiMe}_{4}\right)$.

\subsection{Synthesis of the Ligands}

2.2.1. General Method. To a hot solution of 4-phenyl thiosemicarbazide $(3.34 \mathrm{~g}, 20 \mathrm{mmol})$ in methanol $(100 \mathrm{~mL})$ was added a solution of acetone $(1.47 \mathrm{~mL}, 20 \mathrm{mmol})$ in $40 \mathrm{~mL}$ of methanol with a few drops of glacial acetic acid. The reaction mixture was refluxed for $2-3 \mathrm{~h}$ and stirred for $24 \mathrm{~h}$ at room temperature. The solid product was filtered, washed several times with ethanol, and dried in vacuo. A similar procedure was applied using o-chloro-benzaldehyde $(2.25 \mathrm{~mL}$, $20 \mathrm{mmol}$ ) in $60 \mathrm{~mL}$ of methanol, m-hydroxy-benzaldehyde $(2.44 \mathrm{~g}, 20 \mathrm{mmol})$ in $60 \mathrm{~mL}$ of methanol, naphthaldehyde $(2.72 \mathrm{~mL}, 20 \mathrm{mmol})$ in $40 \mathrm{~mL}$ of methanol, or 1-nitro-2naphthaldehyde $(4.02 \mathrm{~g}, 20 \mathrm{mmol})$ in $70 \mathrm{~mL}$ of methanol. Single crystals suitable for X-ray crystallography for both HTSC $^{3}$ and HTSC $^{4}$ were obtained by slow evaporation of the solvent at room temperature.

2.2.2. 4-Phenyl-1-acetone Thiosemicarbazone, $\operatorname{HTSC}^{1}$ (1). Colorless solid. Yield 78\%. Anal. for $\mathrm{C}_{10} \mathrm{H}_{13} \mathrm{~N}_{3} \mathrm{~S}(207.30 \mathrm{~g} / \mathrm{mol})$ : calcd. C 57.94, H 6.32, N 20.27, S 15.47; found C 58.07, H 6.48, $\mathrm{N} 20.09$, S 15.40. FAB(+)-MS: $m / z 207.3\left(\mathrm{M}^{+}, 100 \%\right)$. IR (KBr): $\nu=3251$ (NHPh), $3182(\mathrm{NHCS}), 1600(\mathrm{C}=\mathrm{N}), 820,1078(\mathrm{C}=\mathrm{S})$ $\mathrm{cm}^{-1} .{ }^{1} \mathrm{H}$ NMR $\left(\mathrm{DMSO}-\mathrm{d}_{6}\right): \delta=2.0\left(\mathrm{~s}, \mathrm{CH}_{3}\right) ; 7.16\left(\mathrm{t}, 1 \mathrm{H}_{\mathrm{para}}\right.$, $\mathrm{NHPh}, J=7.5 \mathrm{~Hz}$ ), $7.33\left(\mathrm{t}, 2 \mathrm{H}_{\text {meta }}, \mathrm{NHPh}, J=8.1 \mathrm{~Hz}\right), 7.61$ (d, $\left.2 \mathrm{H}_{\text {ortho }}, \mathrm{NHPh}, J=7.5 \mathrm{~Hz}\right), 9.83$ (s, $\left.1 \mathrm{H}, \mathrm{NHPh}\right) ; 10.35$ (s,

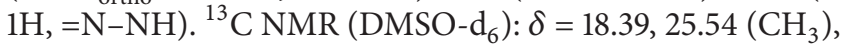
$125.36,128.48,130.48,139.52(\mathrm{NHPh}) ; 153.21(\mathrm{HC}=\mathrm{N}) ; 176.78$ $(\mathrm{C}=\mathrm{S})$.

2.2.3. 4-Phenyl-1-(2'-chlorobenzaldehyhe $)$ Thiosemicarbazone, HTSC $^{2}$ (2). Yellow solid. Yield 72\%. Anal. for $\mathrm{C}_{14} \mathrm{H}_{12} \mathrm{~N}_{3} \mathrm{ClS}$ (289.79 g/mol): calcd. C 58.03, H 4.17, N 14.50, Cl 12.23, S 11.07; found $\mathrm{C}$, 57.92, $\mathrm{H}$ 4.04, $\mathrm{N}$ 14.73, $\mathrm{Cl} 12.15, \mathrm{~S}$ 11.21. FAB(+)MS: $m / z 290.70\left(\mathrm{MH}^{+}, 100 \%\right)$. IR (KBr): $v=3305(\mathrm{NHPh})$, 3166 (NHCS), $1600(\mathrm{C}=\mathrm{N}), 835,1065(\mathrm{C}=\mathrm{S}) \mathrm{cm}^{-1} .{ }^{1} \mathrm{H}$ NMR $\left(\right.$ DMSO- $\left._{6}\right): \delta=8.46\left(\mathrm{~d}, \mathrm{H}^{3^{\prime}}, J=7.5 \mathrm{~Hz}\right), 7.50\left(\mathrm{~m}, \mathrm{H}^{4^{\prime}}\right), 7.22$ $\left(\mathrm{t}, \mathrm{H}^{5^{\prime}}, J=7.2 \mathrm{~Hz}\right), 7.33\left(\mathrm{~d}, \mathrm{H}^{6^{\prime}}, J=8.0 \mathrm{~Hz}\right) ; 7.58$ (d, $2 \mathrm{H}_{\text {ortho }}$, $\mathrm{NHPh}, J=8.7 \mathrm{~Hz}), 7.38\left(\mathrm{t}, 2 \mathrm{H}_{\text {meta }}, \mathrm{NHPh}, J=8.4 \mathrm{~Hz}\right), 7.16$ $\left(\mathrm{t}, 1 \mathrm{H}_{\text {para }}, \mathrm{NHPh}, J=7.5 \mathrm{~Hz}\right) ; 8.59(\mathrm{~s}, 1 \mathrm{H}, \mathrm{HC}=\mathrm{N}) ; 10.22,9.83$ $(\mathrm{s}, 1 \mathrm{H}, \mathrm{NHPh}) ; 12.03,10.35(\mathrm{~s}, 1 \mathrm{H},=\mathrm{N}-\mathrm{NH}) .{ }^{13} \mathrm{C} \mathrm{NMR}$ $\left(\right.$ DMSO-d $\left._{6}\right): \delta=124.78,126.47,128.29,129.17,130.98,133.78$ ( $\mathrm{Ph}-\mathrm{CH}=\mathrm{N}-$ ); 125.37, 128.48, 130.29, 139.38 (NHPh); 153.22 $(\mathrm{HC}=\mathrm{N}) ; 176.92(\mathrm{C}=\mathrm{S})$.

2.2.4. 4-Phenyl-1-(3'-hydroxybenzaldehyde) Thiosemicabazone, $\operatorname{HTSC}^{3}$ (3). Colorless crystals. Yield 87\%. Anal. for $\mathrm{C}_{14} \mathrm{H}_{13}$. $\mathrm{N}_{3} \mathrm{OS}$ (271.34 g/mol): calcd. C 61.97, H 4.83, N 15.49, S 11.82; found $\mathrm{C} 60.65, \mathrm{H}$ 4.95, $\mathrm{N}$ 15.16, S 11.64. $\mathrm{FAB}(+)-\mathrm{MS}: \mathrm{m} / z$ $272.25\left(\mathrm{MH}^{+}, 100 \%\right)$. IR $(\mathrm{KBr}): v=3290(\mathrm{NHPh}), 3140$ (NHCS), $1598(\mathrm{C}=\mathrm{N}), 825,1020(\mathrm{C}=\mathrm{S}) \mathrm{cm}^{-1} \cdot{ }^{1} \mathrm{H}$ NMR

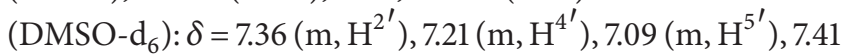
$\left(\mathrm{d}, \mathrm{H}^{6^{\prime}}, J=7.8 \mathrm{~Hz}\right) ; 7.57$ (d, 2H $\left.\mathrm{H}_{\text {ortho }}, \mathrm{NHPh}, J=7.5 \mathrm{~Hz}\right), 7.33$ (t, $\left.2 \mathrm{H}_{\text {meta }}, \mathrm{NHPh}, J=8.1 \mathrm{~Hz}\right), 7.15\left(\mathrm{t}, 1 \mathrm{H}_{\text {para }}, \mathrm{NHPh}, J=7.2 \mathrm{~Hz}\right)$; 8.07 (s, 1H, $\mathrm{HC}=\mathrm{N}) ; 9.56(\mathrm{~s}, 1 \mathrm{H}, \mathrm{OH}) ; 10.34,9.91(\mathrm{~s}, 1 \mathrm{H}$, $\mathrm{NHPh}), 11.77,10.07$ (s, 1H, =N-NH). ${ }^{13} \mathrm{C}$ NMR $\left(\mathrm{DMSO}_{6}\right)$ : $\delta=114.68,118.93,125.80,130.05,135.32,158.02(\mathrm{Ph}-\mathrm{CH}=\mathrm{N}-)$; $121.84,125.31,128.06,139.1(\mathrm{NHPh}) ; 152.79(\mathrm{HC}=\mathrm{N}) ; 193.17$ $(\mathrm{C}=\mathrm{S})$.

2.2.5. 4-Phenyl-1-naphthaldehyde Thiosemicarbazone, HTSC (4). Rectangular-shaped yellow crystals. Yield 75\%. Anal. for $\mathrm{C}_{18} \mathrm{H}_{15} \mathrm{~N}_{3} \mathrm{~S}$ (305.39 g/mol): calcd. C 70.79, H 4.95, N 13.76, 
S 10.50; found: C 70.93, H 4.80, N 13.85, S 10.38. FAB(+)MS: $m / z 305.40\left(\mathrm{M}^{+}, 100 \%\right)$. IR (KBr): $v=3327(\mathrm{NHPh})$, 3165 (NHCS), $1600(\mathrm{C}=\mathrm{N}), 815,1088(\mathrm{C}=\mathrm{S}) \mathrm{cm}^{-1} \cdot{ }^{1} \mathrm{H}$ NMR $\left(\right.$ DMSO $\left.\mathrm{d}_{6}\right): \delta=7.33\left(\mathrm{~d}, \mathrm{H}^{2^{\prime}}, 7.8 \mathrm{~Hz}\right), 7.67\left(\mathrm{t}, \mathrm{H}^{3^{\prime}}, 7.2 \mathrm{~Hz}\right), 8.34$ $\left(\mathrm{d}, \mathrm{H}^{4^{\prime}}, 8.4 \mathrm{~Hz}\right), 8.47\left(\mathrm{~d}, \mathrm{H}^{5^{\prime}}, \mathrm{H}^{8^{\prime}}, J=6.0 \mathrm{~Hz}\right), 7.67\left(\mathrm{t}, \mathrm{H}^{6^{\prime}}, J=\right.$ $7.2 \mathrm{~Hz}), 8.02\left(\mathrm{t}, \mathrm{H}^{7^{\prime}}, J=7.2 \mathrm{~Hz}\right) ; 7.39\left(\mathrm{t}, 2 \mathrm{H}_{\text {meta }}, \mathrm{NHPh}, J=\right.$ $7.8 \mathrm{~Hz}), 7.16\left(\mathrm{t}, 1 \mathrm{H}_{\text {para }}, \mathrm{NHPh}, J=7.2 \mathrm{~Hz}\right), 7.61$ (d, $2 \mathrm{H}_{\text {ortho }}$, $\mathrm{NHPh}, J=7.2 \mathrm{~Hz}) ; 9.08(\mathrm{~s}, 1 \mathrm{H}, \mathrm{HC}=\mathrm{N}) ; 9.84,10.35$ (s, $1 \mathrm{H}$, $\mathrm{NHPh}$ ); 10.20, 11.89 (s, 1H, =N-NH). ${ }^{13} \mathrm{C}$ NMR (DMSO$\left.\mathrm{d}_{6}\right): \delta=122.94,125.83,126.05,126.62,127.69,129.37,130.87$, $131.15,133.83,141.45$ (Naphthoyl); 125.38, 126.25, 128.57, 139.54 (NHPh), $153.25(\mathrm{HC}=\mathrm{N}) ; 176.38(\mathrm{C}=\mathrm{S})$.

2.2.6. 4-Phenyl-1-(1' -nitro-2' -naphthaldehyde) Thiosemicarbazone, $\operatorname{HTSC}^{5}$ (5). Yellow solid. Yield 85\%. Anal. for $\mathrm{C}_{18} \mathrm{H}_{14}$. $\mathrm{N}_{4} \mathrm{O}_{2} \mathrm{~S}$ (350.39 g/mol): calcd. C 61.69, H 4.03, N 16.00, S 9.15; found: $\mathrm{C} 61.54, \mathrm{H} 4.10, \mathrm{~N} 15.82, \mathrm{~S}$ 8.94. $\mathrm{FAB}(+)-\mathrm{MS}: m / z$ $350.40\left(\mathrm{M}^{+}, 100 \%\right)$. IR (KBr): $v=3250(\mathrm{NHPh}), 3174$ (NHCS), 1713, $1626(\mathrm{C}=\mathrm{N}), 820,1047(\mathrm{C}=\mathrm{S}) \mathrm{cm}^{-1}$. ${ }^{1} \mathrm{H}$ NMR (DMSO$\left.\mathrm{d}_{6}\right): \delta=8.40\left(\mathrm{~d}, \mathrm{H}^{3^{\prime}}, J=8.5 \mathrm{~Hz}\right), 8.09\left(\mathrm{~d}, \mathrm{H}^{4^{\prime}}, J=8.5 \mathrm{~Hz}\right), 8.22$ $\left(\mathrm{d}, \mathrm{H}^{5^{\prime}}, \mathrm{H}^{8^{\prime}}, J=6.0 \mathrm{~Hz}\right), 7.86\left(\mathrm{t}, \mathrm{H}^{6^{\prime}}, \mathrm{H}^{7^{\prime}}, J=6.0 \mathrm{~Hz}\right) ; 7.61(\mathrm{~d}$, $\left.2 \mathrm{H}_{\text {ortho }}, \mathrm{NHPh}, J=8.5 \mathrm{~Hz}\right), 7.33\left(\mathrm{t}, 2 \mathrm{H}_{\text {meta }}, \mathrm{NHPh}, J=\right.$ $6.5 \mathrm{~Hz}$ ), 7.15 (t, $1 \mathrm{H}_{\text {para }}$, NHPh, $\left.J=7.5 \mathrm{~Hz}\right) ; 10.15$ (s, 1H, NHPh), 9.83, $10.34(\mathrm{~s}, 1 \mathrm{H},=\mathrm{N}-\mathrm{NH}) .{ }^{13} \mathrm{C}$ NMR $\left(\mathrm{DMSO}_{-} \mathrm{d}_{6}\right): \delta=118.28$, $123.71,126.01,129.17,130.84,132.22,136.47,137.96,153.24$, 163.47 (Naphthoyl); 122.65, 125.36, 128.49, 139.5 (NHPh); $176.76(\mathrm{HC}=\mathrm{N}) ; 189.98(\mathrm{C}=\mathrm{S})$.

\subsection{Synthesis of the Palladium(II) Complexes}

2.3.1. General Method. A solution of $\mathrm{K}_{2}\left[\mathrm{PdCl}_{4}\right](0.163 \mathrm{~g}$, $0.5 \mathrm{mmol})$ in ethanol $(60 \mathrm{~mL})$ or a solution of $\left[\mathrm{Pd}(\mathrm{acac})_{2}\right]$ $(0.153 \mathrm{~g}, 0.5 \mathrm{mmol})$ in dichloromethane/ethanol $(2: 1,45 \mathrm{~mL})$ was added dropwise to a stirred hot solution of the corresponding thiosemicarbazone $(1.0 \mathrm{mmol})$ in $70 \mathrm{~mL}$ of methanol. Then, sodium acetate $(0.082 \mathrm{~g}, 1 \mathrm{mmol})$ in $5 \mathrm{~mL}$ of water was added. The solution was refluxed for $2-3 \mathrm{~h}$ and stirred for $24 \mathrm{~h}$ at room temperature. The precipitate was collected by filtration, washed three times with ethanol $(30 \mathrm{~mL})$, and dried under vacuum. For the complex $\left[\mathrm{Pd}\left(\mathrm{TSC}^{1}\right)_{2}\right](\mathbf{6})$, single crystals suitable for X-ray diffraction studies were grown by slow evaporation from an acetone solution.

2.3.2.Bis[4-phenyl-1-(acetone) Thiosemicarbazonato]palladium (II), $\left[\mathrm{Pd}\left(\mathrm{TSC}^{1}\right)_{2}\right]$ (6). Square-shaped orange crystals. Yield $65 \%$. Anal. for $\mathrm{C}_{20} \mathrm{H}_{24} \mathrm{~N}_{6} \mathrm{~S}_{2} \mathrm{Pd}(518.99 \mathrm{~g} / \mathrm{mol})$ : calcd. C 46.28, $\mathrm{H}$ 4.66, N 16.19, S 12.36; found $\mathrm{C} 46.05, \mathrm{H} 4.74, \mathrm{~N} 16.21$, $\mathrm{S}$ 12.23. $\mathrm{FAB}(+)-\mathrm{MS}: m / z 518.50\left(\mathrm{M}^{+}, 75 \%\right)$. IR $(\mathrm{KBr}): v=$ $3375(\mathrm{NHPh}), 1590(\mathrm{C}=\mathrm{N}), 800,964(\mathrm{C}=\mathrm{S}) \mathrm{cm}^{-1} \cdot{ }^{1} \mathrm{H}$ NMR $\left(\mathrm{DMSO}_{-} \mathrm{d}_{6}\right): \delta=2.18,2.35\left(\mathrm{~s}, 12 \mathrm{H}, 4 \mathrm{CH}_{3}\right) ; 7.62$ (d, $4 \mathrm{H}_{\text {ortho }}$, $J=7.9 \mathrm{~Hz}, \mathrm{NHPh}), 7.26\left(\mathrm{t}, 4 \mathrm{H}_{\text {meta }}, J=7.7 \mathrm{~Hz}, \mathrm{NHPh}\right), 6.93$ (t, $\left.2 \mathrm{H}_{\text {para }}, J=7.5 \mathrm{~Hz}, \mathrm{NHPh}\right) ; 9.34(\mathrm{~s}, 2 \mathrm{H}, \mathrm{NHPh}) .{ }^{13} \mathrm{C} \mathrm{NMR}$ $\left(\mathrm{DMSO}_{6}\right): \delta=19.65,22.08\left(\mathrm{CH}_{3}\right), 119.06,123.15,129.01$, $141.80(\mathrm{NHPh}) ; 154.50(\mathrm{HC}=\mathrm{N}) ; 176.20(\mathrm{C}=\mathrm{S})$.
2.3.3. Bis[4-phenyl-1-(2'-chlorobenzaldehyde) Thiosemicarbazonato $]$ palladium (II), $\left[\mathrm{Pd}\left(\mathrm{TSC}^{2}\right)_{2}\right]$ (7). Red solid. Yield $60 \%$. Anal. for $\mathrm{C}_{28} \mathrm{H}_{22} \mathrm{~N}_{6} \mathrm{Cl}_{2} \mathrm{~S}_{2} \mathrm{Pd}(683.97 \mathrm{~g} / \mathrm{mol})$ : calcd. C $49.17, \mathrm{H}$ 3.24, N 12.29, Cl 10.37, S 9.38; found C, 49.26, H 3.12, N 12.36, Cl 10.45, S 9.25. FAB(+)-MS: $m / z 648.5\left(\mathrm{M}^{+}-\mathrm{Cl}, 65 \%\right)$. IR $(\mathrm{KBr}): \nu=3375(\mathrm{NHPh}), 1580(\mathrm{C}=\mathrm{N}), 795,927(\mathrm{C}=\mathrm{S}) \mathrm{cm}^{-1}$. ${ }^{1} \mathrm{H}$ NMR $\left(\mathrm{DMSO}-\mathrm{d}_{6}\right): \delta=8.29\left(\mathrm{~d}, \mathrm{H}^{3^{\prime}}, J=8.1 \mathrm{~Hz}\right), 7.52(\mathrm{~m}$, $\left.\mathrm{H}^{4^{\prime}}\right), 7.28\left(\mathrm{t}, \mathrm{H}^{5^{\prime}}, J=7.8 \mathrm{~Hz}\right), 7.42\left(\mathrm{~d}, \mathrm{H}^{6^{\prime}}, J=8.1 \mathrm{~Hz}\right) ; 7.59(\mathrm{~d}$, $4 \mathrm{H}_{\text {ortho }}, \mathrm{NHPh}, J=8.1 \mathrm{~Hz}$ ), 7.19 (t, $4 \mathrm{H}_{\text {meta }}, \mathrm{NHPh}, J=8.1 \mathrm{~Hz}$ ), $6.98\left(\mathrm{t}, 2 \mathrm{H}_{\text {para }}\right.$, NHPh, $\left.J=7.2 \mathrm{~Hz}\right) ; 8.0(\mathrm{~s}, 2 \mathrm{H}, \mathrm{HC}=\mathrm{N}) ; 9.34$, $9.92(\mathrm{~s}, 1 \mathrm{H}, \mathrm{NHPh}) .{ }^{13} \mathrm{C}$ NMR (DMSO-d 6 ): $\delta=119.05,120.83$, 125.01, 126.72, 127.38, 138.77 (Ph-CH=N-); 121.94, 127.90, 129.0, $141.81(\mathrm{NHPh}) ; 166.48(\mathrm{HC}=\mathrm{N}) ; 169.19(\mathrm{C}=\mathrm{S})$.

2.3.4. Bis[4-phenyl-1-(3'-hydroxybenzaldehyde) Thiosemicarbazonato $]$ palladium(II), $\left[\mathrm{Pd}\left(\mathrm{TSC}^{3}\right)_{2}\right](\mathbf{8})$. Orange solid. Yield 68\%. Anal. for $\mathrm{C}_{28} \mathrm{H}_{24} \mathrm{~N}_{6} \mathrm{O}_{2} \mathrm{~S}_{2} \mathrm{Pd}$ (647.08 g/mol): calcd. C 51.97, H 3.74, N 12.99, S 9.91; found C 52.05, H 3.66, N 13.04, S 9.83. $\mathrm{FAB}(+)-\mathrm{MS}: m / z 646.95\left(\mathrm{M}^{+}, 55 \%\right)$. IR (KBr): $v=3300$ $(\mathrm{NHPh}), 1585(\mathrm{C}=\mathrm{N}), 800,930(\mathrm{C}=\mathrm{S}) \mathrm{cm}^{-1} .{ }^{1} \mathrm{H} \mathrm{NMR}$ $\left(\right.$ DMSO- $\left._{6}\right): \delta=7.02\left(\mathrm{~d}, 2 \mathrm{H}^{4^{\prime}}, 2 \mathrm{H}^{6^{\prime}}, J=8.4 \mathrm{~Hz}\right) 7.48\left(\mathrm{t}, 2 \mathrm{H}^{5^{\prime}}\right.$, $J=7.5 \mathrm{~Hz}) ; 7.60$ (d, $\left.4 \mathrm{H}_{\text {ortho }}, \mathrm{NHPh}, J=7.8 \mathrm{~Hz}\right), 7.28\left(\mathrm{t}, 4 \mathrm{H}_{\text {meta }}\right.$, $\mathrm{NHPh}, J=8.4 \mathrm{~Hz}), 6.92\left(\mathrm{t}, 2 \mathrm{H}_{\text {para }}\right.$, NHPh, $\left.J=7.5 \mathrm{~Hz}\right) ; 7.81(\mathrm{~s}$, $2 \mathrm{H}, \mathrm{HC}=\mathrm{N}), 8.45(\mathrm{~d}, \mathrm{OH}, J=7.5 \mathrm{~Hz}) ; 9.46$ (s, 2H, NHPh, $J=$ $7.5 \mathrm{~Hz}) .{ }^{13} \mathrm{C}$ NMR $\left(\mathrm{DMSO}-\mathrm{d}_{6}\right): \delta=110.71,121.75,130.69$, 133.47, 155.19 (Ph-CH=N-); 119.04, 120.0, 128.62, 141.23 $(\mathrm{NHPh}) ; 158.37(\mathrm{HC}=\mathrm{N}) ; 167.06(\mathrm{C}=\mathrm{S})$.

2.3.5.Bis[4-phenyl-1-naphthaldehyde Thiosemicarbazonato]palladium(II), [Pd(TSC $)_{2}^{4}$ ] (9). Orange solid. Yield 61\%. Anal. for $\mathrm{C}_{36} \mathrm{H}_{28} \mathrm{~N}_{6} \mathrm{~S}_{2} \mathrm{Pd}(715.20 \mathrm{~g} / \mathrm{mol})$ : calcd. C 60.46, H 3.95, N 11.75, S 8.97; found: C 60.32, H 4.05, N 11.81, S 8.84. FAB(+)MS: $m / z 716.30\left(\mathrm{MH}^{+}, 58 \%\right)$ IR (KBr): $\nu=3373(\mathrm{NHPh}), 1588$ $(\mathrm{C}=\mathrm{N}), 780,1032(\mathrm{C}=\mathrm{S}) \mathrm{cm}^{-11} \mathrm{H}$ NMR $\left(\mathrm{DMSO}-\mathrm{d}_{6}\right): \delta=8.44$ $\left(\mathrm{d}, 2 \mathrm{H}^{2^{\prime}}, J=9.0 \mathrm{~Hz}\right), 7.85\left(\mathrm{~m}, 2 \mathrm{H}^{3^{\prime}}\right), 8.24\left(\mathrm{~d}, 2 \mathrm{H}^{4^{\prime}}, 2 \mathrm{H}^{5^{\prime}}, J=\right.$ $9.0 \mathrm{~Hz}), 7.85\left(\mathrm{~m}, 2 \mathrm{H}^{6^{\prime}}, 2 \mathrm{H}^{7^{\prime}}\right), 8.14\left(\mathrm{~d}, 2 \mathrm{H}^{8^{\prime}}, J=6.0 \mathrm{~Hz}\right) ; 7.60(\mathrm{~d}$, $\left.4 \mathrm{H}_{\text {ortho }}, \mathrm{NHPh}, J=6.0 \mathrm{~Hz}\right), 7.33\left(\mathrm{t}, 4 \mathrm{H}_{\text {meta }}, \mathrm{NHPh}, J=8.0 \mathrm{~Hz}\right)$, $7.15\left(\mathrm{t}, 2 \mathrm{H}_{\text {para }}, \mathrm{NHPh}, J=8.5 \mathrm{~Hz}\right) ; 9.83,10.15,10.33(\mathrm{~s}, 2 \mathrm{H}$, $\mathrm{NHPh}) .{ }^{13} \mathrm{C}$ NMR (DMSO-d 6 ): $\delta=118.05,121.04,123.64$, $124.34,126.12,129.09,132.50,134.30,136.47,139.52$ (Naphthoyl); 125.14, 126.77, 128.71, $141.04(\mathrm{NHPh}), 165.62(\mathrm{HC}=\mathrm{N})$; $175.72(\mathrm{C}=\mathrm{S})$.

2.3.6.Bis[4-phenyl-1-(1'-nitro-2'-naphthaldehyde) Thiosemicarbazonato]palladium(II), $\left[\mathrm{Pd}\left(\mathrm{TSC}^{4}\right)_{2}\right]$ (10). Orange solid. Yield 50\%. Anal. for $\mathrm{C}_{36} \mathrm{H}_{26} \mathrm{~N}_{8} \mathrm{O}_{4} \mathrm{~S}_{2} \mathrm{Pd}(805.19 \mathrm{~g} / \mathrm{mol})$ : calcd. C 53.70, H 3.25, N 13.92, S 7.96; found: C 53.64, H 3.15, N 13.86, S 7.78. FAB(+)-MS: $m / z 787.10\left(\mathrm{M}^{+}-\mathrm{H}_{2} \mathrm{O}, 100 \%\right)$. IR $(\mathrm{KBr}): \nu=3374(\mathrm{NHPh}), 1578(\mathrm{C}=\mathrm{N}), 790,1017(\mathrm{C}=\mathrm{S}) \mathrm{cm}^{-1}$. ${ }^{1} \mathrm{H}$ NMR (DMSO, $\left.\mathrm{d}_{6}\right): \delta=7.80\left(\mathrm{t}, 2 \mathrm{H}^{3^{\prime}}, J=9.0 \mathrm{~Hz}\right), 8.38(\mathrm{~d}$, $\left.2 \mathrm{H}^{4^{\prime}}, 2 \mathrm{H}^{5^{\prime}}, J=9.0 \mathrm{~Hz}\right), 7.80\left(\mathrm{t}, 2 \mathrm{H}^{6^{\prime}}, 2 \mathrm{H}^{7^{\prime}}, J=6.0 \mathrm{~Hz}\right), 7.31(\mathrm{~m}$, $\left.2 \mathrm{H}^{8^{\prime}}\right) ; 7.62\left(\mathrm{~d}, 4 \mathrm{H}_{\text {ortho }}, \mathrm{NHPh}, J=9.0 \mathrm{~Hz}\right), 7.26\left(\mathrm{t}, 4 \mathrm{H}_{\text {meta }}\right.$, $\mathrm{NHPh}, J=9.0 \mathrm{~Hz}), 6.92\left(\mathrm{t}, 2 \mathrm{H}_{\text {para }}\right.$, NHPh, $\left.J=6.0 \mathrm{~Hz}\right) ; 9.33$, 9.59 (s, 2H, NHPh). ${ }^{13} \mathrm{C} \mathrm{NMR}\left(\mathrm{DMSO}-\mathrm{d}_{6}\right): \delta=113.57,123.44$, $128.20,129.38,130.13,132.36,133.25,137.41,152.57,157.61$ 
(Naphthoyl); 121.22, 124.54, 127.75, 138.45 (NHPh); 178.83 $(\mathrm{HC}=\mathrm{N}) ; 189.50(\mathrm{C}=\mathrm{S})$.

2.4. Crystal Structure Determinations. Crystallographic measurements were made using an IPDS1 diffractometer (graphite monochromated Mo-K $\alpha$ radiation $(\lambda=0.71073 \AA)$ ). Data were collected using $\Phi$ scan technique with a scan width of $0.7^{\circ}$. The structures were solved by direct methods using the program SIR2004 [28] and were refined using anisotropic approximation for the nonhydrogen atoms using SHELXL-97 software [29].

\subsection{Biological Activity}

2.5.1. Cell Culture. The H460 (human lung large cell carcinoma), M-14 (human amelanotic melanoma), DU145 (human prostate carcinoma), MCF-7 (human breast adenocarcinoma), HT-29 (human colon adenocarcinoma), and K562 (human chronic myelogenous leukemia) cell lines were obtained from the research laboratory of the Faculty of Sciences and Philosophy, Universidad Peruana Cayetano Heredia. All the cells were cultured in Dulbecco's Modified Eagle Medium (DMEM) supplemented with $10 \%$ fetal calf serum and $50 \mu \mathrm{g} / \mathrm{mL}$ gentamycin in humidified $5 \% \mathrm{CO}_{2} / 95 \%$ air at $37^{\circ} \mathrm{C}$.

2.6. Assessment of Cytotoxicity. The assay was performed as described previously [30]. Briefly, 3000-5000 cells were inoculated in each well of 96-well tissue culture plates and incubated at $37^{\circ} \mathrm{C}$ with their corresponding culture medium during $24 \mathrm{~h}$. The ligands $\operatorname{HTSC}^{1-5}(10-250 \mu \mathrm{M})$, palladium(II) complexes $(0.01-10 \mu \mathrm{M})$, or cisplatin $(1-10 \mu \mathrm{M})$ in DMSO were then added and incubated for $48 \mathrm{~h}$ at $37^{\circ} \mathrm{C}$ with a highly humidified atmosphere, $5 \% \mathrm{CO}_{2}$ and $95 \%$ air. After the incubating period, cell monolayers were fixed with $10 \%$ trichloroacetic acid and stained for 20 minutes using the sulforhodamine $\mathrm{B}$ dye. Then, the excess dye was removed by washing repeatedly with $1 \%$ acetic acid. The protein-bound dye was solubilized with $10 \mathrm{mM}$ Tris buffer ( $\mathrm{pH} 10.5$ ) and the absorbance values were obtained at $510 \mathrm{~nm}$ using a microplate reader. The $\mathrm{IC}_{50}$ value was defined as the concentration of a test sample resulting in a $50 \%$ reduction of absorbance as compared with untreated controls and was determined by linear regression analysis.

\section{Results and Discussion}

3.1. Synthesis and Characterization. The ligands $\mathrm{HTSC}^{1-5}$ were prepared according to the literature [31-33], as shown in Scheme 1 . The ligands were obtained in good yields (72-87\%) and characterized by elemental analysis and FT-IR, FAB $(+)$ mass, and NMR $\left({ }^{1} \mathrm{H},{ }^{13} \mathrm{C}\right)$ spectroscopy.

The palladium(II) complexes (Scheme 2) were obtained in satisfactory yield (50-68\%) and characterized by elemental analysis and FT-IR, $\mathrm{FAB}(+)$-mass, and $\mathrm{NMR}\left({ }^{1} \mathrm{H},{ }^{13} \mathrm{C}\right)$ spectroscopy.
Analytical and spectroscopy data obtained for the thiosemicarbazone ligands and their palladium(II) complexes are in agreement with the proposed structures.

The ligand $\operatorname{HTSC}^{3}(3)$ and the complex $\left[\operatorname{Pd}\left(\operatorname{TSC}^{1}\right)_{2}\right](6)$ were recrystallized from acetone, and single crystals suitable for X-ray crystallography were obtained, while single crystals of the ligand $\mathrm{HSTC}^{4}(4)$ were obtained by slow evaporation of the solvent from the final reaction mixture.

3.2. Infrared Spectra. The broad bands of the $-\mathrm{NH}$ group observed at $3140-3182 \mathrm{~cm}^{-1}$ in the spectra of the free ligands disappeared in the spectra of the corresponding complexes, thus indicating the deprotonation of the $=\mathrm{N}-\mathrm{NH}-$ group. The strong bands observed in the range of 1598 $1626 \mathrm{~cm}^{-1}$ were assigned to $(\mathrm{C}=\mathrm{N})$ stretching vibrations of the free thiosemicarbazones. These bands were shifted to lower frequencies $\left(10-22 \mathrm{~cm}^{-1}\right)$ after coordination, which is in agreement with the observed behaviour of other bischelate complexes [26, 34-39]. These results indicate the coordination of the azomethine nitrogen to the metal ion. The $v(\mathrm{C}=\mathrm{S})$ vibrations observed at $815-1088 \mathrm{~cm}^{-1}$ in the spectra of the free ligands shift $20-138 \mathrm{~cm}^{-1}$ towards lower frequencies upon complexation, indicating the involvement of the thione sulphur in the bond formation to the metal ion [40,41].

3.3. NMR Spectra. The ${ }^{1} \mathrm{H}$ NMR and ${ }^{13} \mathrm{C}$ NMR spectra of the ligands and their metal complexes were recorded in DMSO$\mathrm{d}_{6}$. In the ${ }^{1} \mathrm{H}$ NMR spectra of the ligands $\operatorname{HTSC}^{1-5}$, the signal of the $=\mathrm{N}-\mathrm{NH}$ proton appears as a singlet at $\delta 10.07-$ 12.03 , while on complexation these signals disappeared, thus indicating the deprotonation of the $=\mathrm{N}-\mathrm{NH}$ group $[25,33$, 42-46]. In the ${ }^{1} \mathrm{H}$ NMR spectra of the ligands $\mathrm{HTSC}^{2-5}$, the signal of the $\mathrm{HC}=\mathrm{N}$ proton appeared as a singlet at $\delta=8.07$ 9.08. These signals are shifted by $0.26-0.59 \mathrm{ppm}$ upfield for $\left[\operatorname{Pd}\left(\operatorname{TSC}^{2-3}\right)_{2}\right]$ complexes $(7,8)$. These results are consistent with the IR spectral data and suggest the coordination of palladium to the imine nitrogen $[24,25,43-45]$. For all ligands, the resonance lines found at $\delta=9.83-10.35$ were assigned to the proton of the NHPh group. The presence of the phenyl group on the terminal amine induces the shift of these signals by $1.9 \mathrm{ppm}$ downfield, as compared to the resonance lines of the $-\mathrm{NH}_{2}$ terminal group found for other thiosemicarbazone derivatives [33,44]. On the other hand, the aromatic proton signals of the phenyl amine group in all the ligands were observed at $\delta=7.15-7.61$, and these resonance lines show the expected calculated multiplicity. For the ligands $\operatorname{HTSC}^{2}$ (2) and $\operatorname{HTSC}^{3}$ (3) the aromatic proton signals of the phenyl fragment bound to the $-\mathrm{CH}=\mathrm{N}$ group were affected by the presence of the chloro and hydroxy substituents in the C-2 $2^{\prime}$ and $\mathrm{C}-3^{\prime}$ positions, respectively, of the phenyl moiety. For the $\operatorname{HTSC}^{2}$ (2) ligand, these signals are shifted downfield for the protons in the positions $\mathrm{C}$ $3^{\prime}(1 \mathrm{ppm})$ and C-4' $(0.1 \mathrm{ppm})$, while for $\operatorname{HTSC}^{3}$ (3) ligand they are shifted upfield for the protons in the positions $\mathrm{C}-2^{\prime}(0.55 \mathrm{ppm})$ and $\mathrm{C}-4^{\prime}(0.21 \mathrm{ppm})$, with respect to the unsubstituted phenyl moiety [33]. For the $\operatorname{HTSC}^{5}$ (5) ligand, the presence of the nitro substituent group in the naphthoyl 
<smiles>NNC(=S)Nc1ccccc1</smiles>

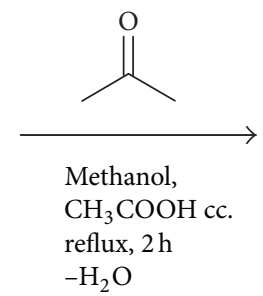<smiles>CC(C)=NNC(=S)Nc1ccccc1</smiles>

(1) HTSC $^{1}$<smiles>[X]c1ccccc1/C=N/NC(=S)Nc1ccccc1</smiles>

(2) $\operatorname{HTSC}^{2}\left(\mathrm{X}=2^{\prime}-\mathrm{Cl}\right)$

(3) $\operatorname{HTSC}^{3}\left(\mathrm{X}=3^{\prime}-\mathrm{OH}\right)$

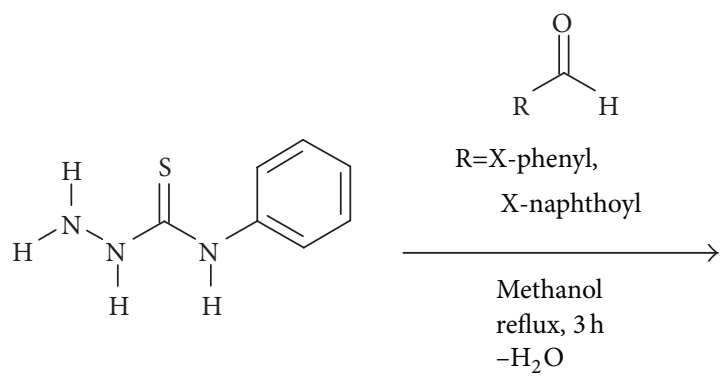<smiles>S=C(N/N=C/c1cccc2ccccc12)Nc1ccccc1</smiles>

(4) HTSC $^{4}$<smiles></smiles>

(5) $\operatorname{HTSC}^{5}$

Scheme 1: Synthesis of 4-phenyl-1-acetone thiosemicarbazone, 4-phenyl-1-benzaldehyde thiosemicarbazone, and 4-phenyl-1-naphthaldehyde thiosemicarbazone ligands.

moiety affected the resonance signals of the aromatic protons. These signals are shifted downfield for the protons in the positions $\mathrm{C}-3^{\prime}(0.73 \mathrm{ppm})$ and $\mathrm{C}-6^{\prime}(0.19 \mathrm{ppm})$, while for the protons in the positions $\mathrm{C}-4^{\prime}, \mathrm{C}-5^{\prime}, \mathrm{C}-7^{\prime}$, and $\mathrm{C}-8^{\prime}$ these are shifted upfield by $0.16-0.25 \mathrm{ppm}$, relative to the HTSC $^{4}$ (4) ligand with the unsubstituted naphthoyl moiety. Thus, the aromatic protons signals in all the ligands do not suffer relevant changes in their chemical shifts after complexation.

In the ${ }^{13} \mathrm{C}$ NMR spectra, the carbon resonance signals of the $\mathrm{C}=\mathrm{N}$ group appear at $\delta=152.8-176.8$. These results are similar to the chemical shifts found for other ligands derived from benzaldehyde thiosemicarbazone $[33,40]$. The $\mathrm{C}=\mathrm{S}$ signals observed at $\delta=176.4-193.2$ are characteristic for the thiocarbonyl group present in all the ligands. For $\left[\operatorname{Pd}\left(\operatorname{TSC}^{1-5}\right)_{2}\right]$ complexes $(6-10)$, the $\mathrm{C}=\mathrm{N}$ and $\mathrm{C}=\mathrm{S}$ signals are shifted downfield by $1.3-13.3 \mathrm{ppm}$ and upfield by $0.5-$ $26.1 \mathrm{ppm}$, respectively, with respect to their ligands. These results confirm the coordination of the thiocarbonyl sulphur and azomethine nitrogen atoms to the palladium(II) ion [36, 47]. For all ligands, the aromatic carbons of the NHPh group 
<smiles>CC(C)=NNC(=S)Nc1ccccc1</smiles>

Or<smiles>[X]c1cccc(/C=N/NC(=S)Nc2ccccc2)c1</smiles>

$\mathrm{X}=\mathrm{Cl}, \mathrm{OH}$<smiles></smiles>

(6) $\left[\operatorname{Pd}\left(\mathrm{TSC}^{1}\right)_{2}\right]$

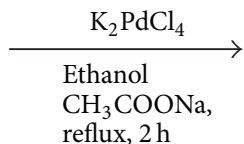<smiles>S=C(N/N=C/c1cccc2ccccc12)Nc1ccccc1</smiles>

$\operatorname{Pd}(\mathrm{acac})_{2}$

Dichloromethane-ethanol $\mathrm{CH}_{3} \mathrm{COONa}$,

reflux, $3 \mathrm{~h}$<smiles>O=[N+]([O-])c1c(/C=N/NC(=S)Nc2ccccc2)ccc2ccccc12</smiles>

Or<smiles>[X]c1ccc(C=[n+]2nc(Nc3ccccc3)s[R7]23sc(Nc2ccccc2)n[n+]3=Cc2ccccc2)cc1</smiles>

(7) $\left[\mathrm{Pd}\left(\mathrm{TSC}^{2}\right)_{2}\right]\left(\mathrm{X}=2^{\prime}-\mathrm{Cl}\right)$

(8) $\left[\mathrm{Pd}\left(\mathrm{TSC}^{3}\right)_{2}\right]\left(\mathrm{X}=3^{\prime}-\mathrm{OH}\right)$

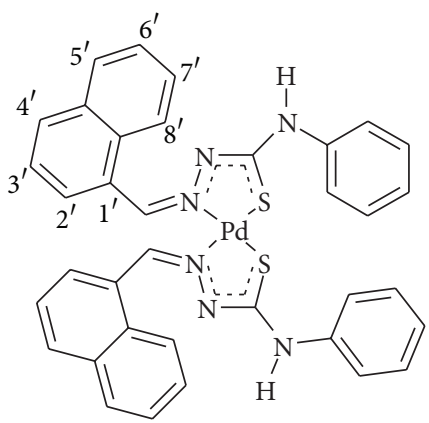

(9) $\left[\operatorname{Pd}\left(\operatorname{TSC}^{4}\right)_{2}\right]$

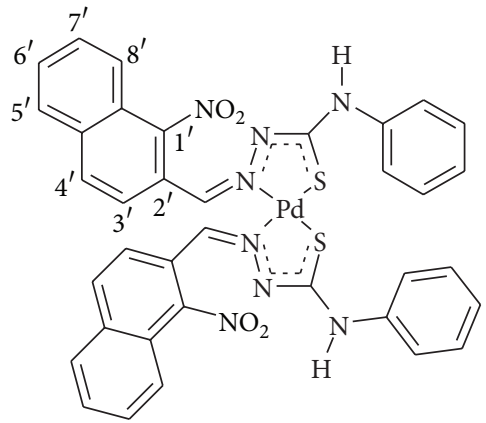

(10) $\left[\operatorname{Pd}\left(\operatorname{TSC}^{5}\right)_{2}\right]$

Scheme 2: Synthesis of palladium(II) bis-chelate complexes of acetone, benzaldehyde, and naphthaldehyde thiosemicarbazone derivatives.

were observed at $\delta=121.8-134.6$, and these chemical shifts are in agreement with those found for other thiosemicarbazone ligands $[33,44]$.

3.4. Structural Data. Crystal data, data collection procedure, structure determination methods, and refinement results for compounds $\mathrm{HTSC}^{3}, \mathrm{HTSC}^{4}$, and $\left[\mathrm{Pd}\left(\mathrm{TSC}^{1}\right)_{2}\right]$ are summarized in Table 1, whereas selected bond lengths and bond angles are presented in Tables 2 and 3.

The molecular structures of $\mathrm{HTSC}^{3}, \mathrm{HTSC}^{4}$, and $\left[\mathrm{Pd}\left(\mathrm{TSC}^{1}\right)_{2}\right]$ are shown in Figures 1,2 , and 3, respectively. The thiocarbazone fragments in the two structures of ligands 
TABLE 1: Crystal data and structure refinement for $\mathrm{HTSC}^{3}, \mathrm{HTSC}^{4}$, and $\left[\mathrm{Pd}\left(\mathrm{TSC}^{1}\right)_{2}\right]$.

\begin{tabular}{|c|c|c|c|}
\hline Compound & HTSC $^{3}$ & HTSC $^{4}$ & {$\left[\mathrm{Pd}\left(\mathrm{TSC}^{1}\right)_{2}\right]$} \\
\hline Empirical formula & $\mathrm{C}_{14} \mathrm{H}_{13} \mathrm{~N}_{3} \mathrm{OS}$ & $\mathrm{C}_{18} \mathrm{H}_{15} \mathrm{~N}_{3} \mathrm{~S}$ & $\mathrm{C}_{20} \mathrm{H}_{24} \mathrm{~N}_{6} \mathrm{~S}_{2} \mathrm{Pd}$ \\
\hline Formula weight & 271.33 & 305.39 & 518.97 \\
\hline Temperature (K) & 213 & 213 & 213 \\
\hline Crystal system & Triclinic & Orthorhombic & Monoclinic \\
\hline Space group & P-1 & $\mathrm{P} 2_{1} 2_{1} 2_{1}$ & $\mathrm{C} 2 / \mathrm{c}$ \\
\hline$a(\AA)$ & $6.3202(7)$ & $5.3471(3)$ & $23.456(2)$ \\
\hline$b(\AA)$ & $10.357(1)$ & $15.7563(9)$ & $7.7080(4)$ \\
\hline$c(\AA)$ & $11.506(1)$ & $16.456(2)$ & $12.3813(10)$ \\
\hline$\alpha\left(^{\circ}\right)$ & $65.95(1)$ & 90 & 90 \\
\hline$\beta\left(^{\circ}\right)$ & $80.14(1)$ & 90 & $97.96(1)$ \\
\hline$\gamma\left({ }^{\circ}\right)$ & $85.32(1)$ & 90 & 90 \\
\hline Volume $\left(\AA^{3}\right)$ & $677.56(13)$ & $1554.91(18)$ & $2216.9(3)$ \\
\hline$Z$ & 2 & 4 & 4 \\
\hline Density $\left(\mathrm{g} / \mathrm{cm}^{3}\right)$ & 1.33 & 1.305 & 1.555 \\
\hline Absorption coeff. $\left(\mathrm{mm}^{-1}\right)$ & 0.234 & 0.208 & 1.044 \\
\hline Crystal size (mm) & $0.7 \times 0.3 \times 0.2$ & $0.7 \times 0.05 \times 0.05$ & $0.4 \times 0.4 \times 0.4$ \\
\hline$\theta$ range for data collect. $\left({ }^{\circ}\right)$ & $3-28$ & $2-26$ & $3-28$ \\
\hline \multirow{3}{*}{ Index ranges } & $-7 \leq h \leq 8$ & $-6 \leq h \leq 6$ & $-30 \leq h \leq 30$ \\
\hline & $-13 \leq k \leq 13$ & $-18 \leq k \leq 19$ & $-9 \leq k \leq 10$ \\
\hline & $-15 \leq l \leq 15$ & $-22 \leq l \leq 22$ & $-16 \leq l \leq 16$ \\
\hline Reflections collected & 7186 & 10232 & 10366 \\
\hline Independent reflections & $\begin{array}{c}2997 \\
\left(R_{\mathrm{int}}=0.024\right)\end{array}$ & $\begin{array}{c}3005 \\
\left(R_{\text {int }}=0.050\right)\end{array}$ & $\begin{array}{c}2662 \\
\left(R_{\text {int }}=0.042\right)\end{array}$ \\
\hline Max./min. transmission & $0.8534 / 0.9547$ & $0.8683 / 0.9897$ & $0.7171 / 0.9674$ \\
\hline Data/parameters & $2997 / 224$ & $3005 / 259$ & $2662 / 180$ \\
\hline Goodness-of-fit on $F^{2}$ & 0.803 & 0.804 & 0.841 \\
\hline \multirow{2}{*}{ Final $R$ indices $[I>2 \sigma(I)]$} & $R_{1}=0.0289$ & $R_{1}=0.0322$ & $R_{1}=0.0235$ \\
\hline & $\omega R_{2}=0.0685$ & $\omega R_{2}=0.0624$ & $\omega R_{2}=0.0442$ \\
\hline \multirow{2}{*}{$R$ indices (all data) } & $R_{1}=0.0478$ & $R_{1}=0.0486$ & $R_{1}=0.0317$ \\
\hline & $\omega R_{2}=0.0717$ & $\omega R_{2}=0.0653$ & $\omega R_{2}=0.0454$ \\
\hline Lgst diff. peak/hole $\left(e \AA^{-3}\right)$ & $0.19 /-0.16$ & $-0.1 / 0.03$ & $-0.31 / 0.07$ \\
\hline
\end{tabular}

TABLE 2: Bond length $(\AA)$ and torsion angles $\left(^{\circ}\right)$ for $\operatorname{HTSC}^{3}$ and HTSC $^{4}$.

\begin{tabular}{llll}
\hline HTSC $^{3}$ & & \multicolumn{3}{c}{ HTSC $^{4}$} \\
\hline C2-N2 & $1.280(2)$ & C8-N3 & $1.278(2)$ \\
N2-N1 & $1.382(2)$ & N3-N2 & $1.380(2)$ \\
N1-C1 & $1.352(2)$ & N2-C7 & $1.351(2)$ \\
C1-N3 & $1.347(2)$ & C7-N1 & $1.351(2)$ \\
C1-S1 & $1.689(1)$ & C7-S1 & $1.688(2)$ \\
N3-C9 & $1.430(2)$ & N1-C1 & $1.414(2)$ \\
C2-N2-N1-C1 & $173.8(1)$ & C8-N3-N2-C7 & $180.0(2)$ \\
N2-N1-C1-N3 & $5.33(2)$ & N3-N2-C7-N1 & $1.0(2)$ \\
N1-C1-N3-C9 & $-177.1(1)$ & N2-C7-N1-C1 & $-176.8(2)$ \\
\hline
\end{tabular}

HTSC $^{3}$ and HTSC $^{4}$ are very similar. Structurally significant is the cis-arrangement between the atoms $\mathrm{N} 2-\mathrm{N} 1-\mathrm{C} 1-\mathrm{N} 3$ $\left(\mathrm{HTSC}^{3}\right)$ and $\mathrm{N} 3-\mathrm{N} 2-\mathrm{C} 7-\mathrm{N} 1\left(\mathrm{HTSC}^{4}\right)$, the torsion angles
TABLE 3: Selected bond lengths $(\AA)$ and angles in $\left(^{\circ}\right)$ for $\left[\operatorname{Pd}\left(\operatorname{TSC}^{1}\right)_{2}\right]$ (6).

\begin{tabular}{lccc}
\hline Distances & \multicolumn{2}{c}{ Angles } \\
\hline Pd1-S1 & $2.270(1)$ & N1-Pd1-S1 & $82.21(4)$ \\
Pd1-N1 & $2.099(1)$ & Pd1-S1-C4 & $95.20(6)$ \\
N1-N2 & $1.421(2)$ & S1-C4-N2 & $125.7(1)$ \\
N2-C4 & $1.290(2)$ & C4-N2-N1 & $112.6(2)$ \\
C4-S1 & $1.773(2)$ & N2-N1-Pd1 & $117.3(1)$ \\
\hline
\end{tabular}

being $5.33(2)^{\circ}$ and $1.0(2)$. All bond lengths in the thiosemicarbazone fragment are identical for the two ligands (Table 2).

The crystal structure of ligand $\mathrm{HTSC}^{3}$ is stabilized by

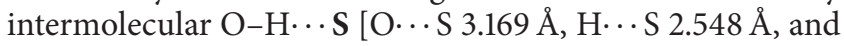
$\mathrm{O}-\mathrm{H} \cdot \mathrm{SS} 136.46^{\circ}$ ] hydrogen bonds which lead to a double chain along the a-axis, as shown in Figure 4. On the other 


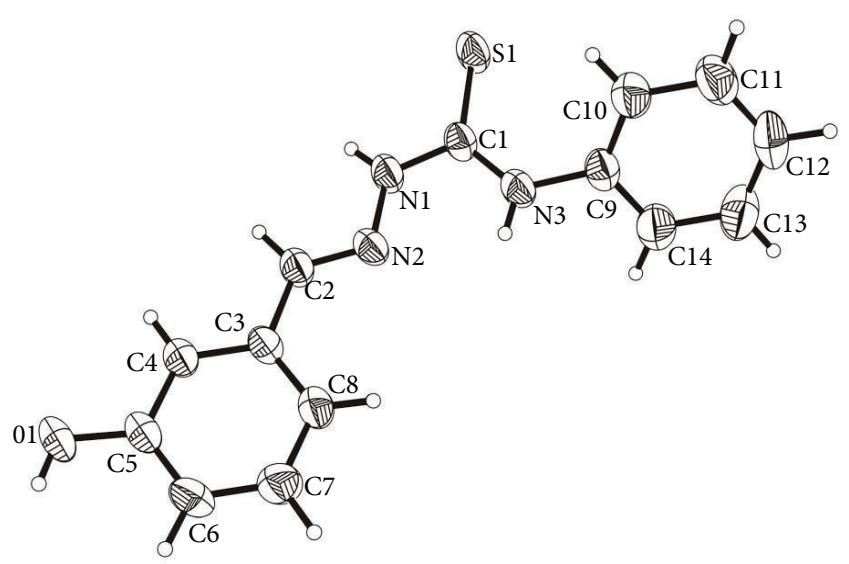

Figure 1: Molecular structure of $\operatorname{HTSC}^{3}$ (3). The displacement ellipsoids are drawn at the $50 \%$ probability.

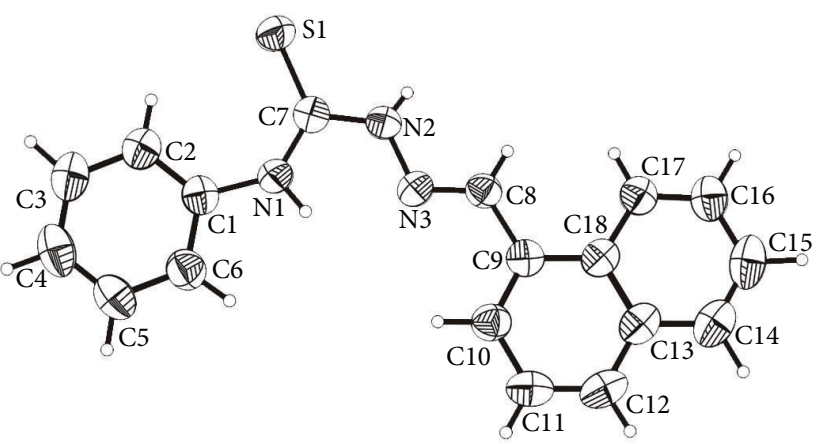

FIgUre 2: Molecular structure of $\operatorname{HTSC}^{4}$ (4). The displacement ellipsoids are drawn at the $50 \%$ probability.

hand, the crystal structure of ligand HTSC $^{4}$ is also stabilized by a $\mathrm{N}-\mathrm{H} \cdots \mathrm{S}$ hydrogen bond with the bond parameters as follows: N ‥S $3.523 \AA, H \cdots S 3.523 \AA$, and N-H-S $158.82^{\circ}$. We found along of a $2_{1}$-screw axis a typical helix structure, as shown in Figure 5.

The complex $\left[\operatorname{Pd}\left(\mathrm{TSC}^{1}\right)_{2}\right]$ (6) (Figure 3) crystallizes in the monoclinic space group $\mathrm{C} 2 / \mathrm{c}$ with four molecules in the unit cell and with a $\mathrm{C}_{2}$ molecular symmetry. The sulfur and nitrogen donor atoms are in a cis arrangement. The deprotonated ligand coordinates bidentately to $\mathrm{Pd}^{\mathrm{II}}$ ion through $\mathrm{S}$ and N. It leads to lengthening of the C4-S1 bond (1.773 $\AA$ ) and shortening of the $\mathrm{N} 2-\mathrm{C} 4$ bond $(1.29 \AA)$ and these results are in agreement with those found for other palladium(II) bischelate complexes of the type $\left[\mathrm{PdL}_{2}\right]$ with thiosemicarbazone ligands $[27,42]$.

The chelate ring with the atoms Pd1, N1, N2, C4, and S1 has an envelope configuration. For the plane formed by the atoms $\mathrm{N} 1, \mathrm{~N} 2, \mathrm{~S} 1$, and $\mathrm{C} 4$, the average deviation is $0.003 \AA$, while the deviation of the Pd atom from this plane is $0.664 \AA$; this distortion indicates a pseudo square planar coordination geometry.

3.5. Antitumor Evaluation. The cytotoxic potential of the ligands derived from thiosemicarbazones and their respective
palladium(II) complexes were investigated in the following six human tumor cell lines: H460, DU145, MCF-7, M14, HT29, and K562. For comparison purposes, the cytotoxicity of cisplatin was evaluated under the same experimental conditions.

The results of the cytotoxic activity of the ligands, palladium(II) complexes, and cisplatin are expressed as IC $_{50}$ values (micromolar concentration inhibiting 50\% cell growth), and these compounds were evaluated in vitro against the different human tumor cell lines, as shown in Table 4. In general, the palladium(II) complexes ( IC $_{50}=0.01-9.87 \mu \mathrm{M}$ ) exhibited higher antiproliferative activity than their free ligands $\left(\mathrm{IC}_{50}=\right.$ $23.48-70.86$ and $>250 \mu \mathrm{M})$. Figure 6 shows the antiproliferative activity of the ligands HTSC $^{1-5}$ and their palladium(II) complexes $\left[\operatorname{Pd}\left(\mathrm{TSC}^{1-5}\right)_{2}\right.$ ] against $\mathrm{H} 460$ and $\mathrm{K} 562$ human tumor cell lines after $48 \mathrm{~h}$ incubation time. These results indicate that the cytotoxicity is enhanced when the ligands are coordinated to the $\mathrm{Pd}(\mathrm{II})$ ion. Probably, the palladium(II) bis-chelate complexes of square planar geometry act as intercalating agents between the pyrimidine and guanine bases of the DNA tumor cells, inducing conformational changes on the DNA double helix specific that finally produce tumor cell death $[33,44,48]$.

All palladium(II) complexes except $\left[\mathrm{Pd}\left(\mathrm{TSC}^{1}\right)_{2}\right](\mathbf{6})$ were more cytotoxic than cisplatin $\left(\mathrm{IC}_{50}=2.85-7.60 \mu \mathrm{M}\right)$ against all the investigated human tumor cell lines. Figure 7 shows a comparison of the magnitude of the $\mathrm{IC}_{50}$ values of the palladium(II) complexes and cisplatin against human breast adenocarcinoma MCF-7 cell line. On the other hand, between all the tested palladium(II) complexes, $\left[\mathrm{Pd}\left(\mathrm{TSC}^{3}\right)_{2}\right] \quad(8)$ and $\left[\operatorname{Pd}\left(\operatorname{TSC}^{5}\right)_{2}\right](10)$ complexes showed greater cytotoxic activity against all human tumor cell lines, with $\mathrm{IC}_{50}$ values of $0.01-0.23$ and $0.65-1.06 \mu \mathrm{M}$, respectively. Therefore, the presence of the 3-hydroxy and 1-nitro substituents groups in the benzene and naphthalene aromatic rings plays an important role in the enhancement the antiproliferative activity $[1,16,27,42]$. The effect of these substituents may be related to their hydrogen-bonding ability compared with the chloro substituent in complex (7). Following this reasoning, the $\left[\mathrm{Pd}\left(\mathrm{TSC}^{3}\right)_{2}\right](8)$ complex, with the 4-phenyl1-( $3^{\prime}$-hydroxy-benzaldehyde) thiosemicarbazone ligand, was also more active than the palladium(II) bis-chelate complex of $3^{\prime}$-cyano-benzaldehyde thiosemicarbazone $\left(\mathrm{IC}_{50}=0.45\right.$ $3.53 \mu \mathrm{M})$ against all human tumor cell lines tested [27]. In addition, complex (8) was found to be about thirteen times more cytotoxic than the gold(I) complex from 4methyl-1- $\left(2^{\prime}\right.$-acetylpyridine) thiosemicarbazone ligand ( $\mathrm{IC}_{50}$ $=1.65 \mu \mathrm{M})$ against the (MCF-7) human breast adenocarcinoma tumor cell line [49]. With respect to the cytotoxic activity shown by the ruthenium(II) complex of the $\left[\mathrm{Ru}(\mathrm{Phen})_{2}(\mathrm{~L})\right] \mathrm{Cl}_{2}$ type, with $\mathrm{L}$ being a 3-methoxy, or 4hydroxy-benzaldehyde thiosemicarbazone ligand $\left(\mathrm{IC}_{50}=\right.$ $3.60 \mu \mathrm{M})$ assayed on the (CEM) human leukemia cell line [24], complex (8) presented higher cytotoxicity at low micromolar concentrations $\left(\mathrm{IC}_{50}=0.02 \mu \mathrm{M}\right)$ tested in vitro against the (K562) chronic myelogenous leukemia cell line. Since the ruthenium complex is octahedral and complex (8) presents a pseudo-planar geometry, the larger cytotoxicity of $(\mathbf{8})$ is in 


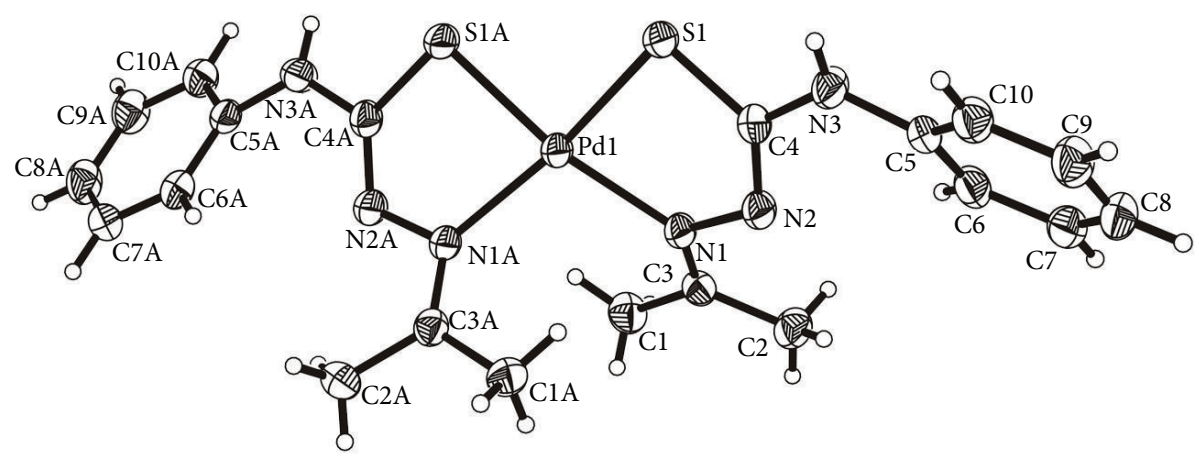

Figure 3: Molecular structure of $\left[\operatorname{Pd}\left(\mathrm{TSC}^{1}\right)_{2}\right](6)$. The displacement ellipsoids are drawn at the $50 \%$ probability.

TABLE 4: $\mathrm{IC}_{50}(\mu \mathrm{m})$ values ${ }^{\mathrm{a}}$ of the ligands $\mathrm{HTSC}^{1-5}$, palladium(II) complexes $\left[\mathrm{Pd}\left(\mathrm{TSC}^{1-5}\right)_{2}\right]$, and cisplatin against the different human tumor cell lines ${ }^{\mathrm{b}}$.

\begin{tabular}{|c|c|c|c|c|c|c|}
\hline Human tumor cell lines & $\mathrm{H} 460$ & DU145 & MCF-7 & M14 & HT-29 & K562 \\
\hline HTSC $^{1}$ & $>250$ & $>250$ & $>250$ & $>250$ & $>250$ & 70.86 \\
\hline HTSC $^{2}$ & $>250$ & 31.55 & 38.05 & $>250$ & $>250$ & 32.89 \\
\hline HTSC $^{3}$ & 23.48 & 26.64 & 34.00 & 28.67 & 25.73 & 35.05 \\
\hline HTSC $^{4}$ & 39.65 & 26.45 & 29.94 & $>250$ & $>250$ & 24.66 \\
\hline HTSC $^{5}$ & 24.95 & 31.60 & 25.46 & 27.31 & 26.72 & 27.76 \\
\hline$\left[\mathrm{Pd}\left(\mathrm{TSC}^{1}\right)_{2}\right]$ & 9.40 & 8.27 & 6.95 & 9.87 & 8.20 & 9.43 \\
\hline$\left[\operatorname{Pd}\left(\operatorname{TSC}^{2}\right)_{2}\right]$ & 2.26 & 2.05 & 1.61 & 2.14 & 1.87 & 1.95 \\
\hline$\left[\mathrm{Pd}\left(\mathrm{TSC}^{3}\right)_{2}\right]$ & 0.23 & 0.01 & 0.13 & 0.05 & 0.05 & 0.02 \\
\hline$\left[\mathrm{Pd}\left(\mathrm{TSC}^{4}\right)_{2}\right]$ & 2.05 & 2.39 & 2.14 & 2.27 & 2.37 & 1.84 \\
\hline$\left[\operatorname{Pd}\left(\operatorname{TSC}^{5}\right)_{2}\right]$ & 0.68 & 0.84 & 0.78 & 1.06 & 1.04 & 0.65 \\
\hline cisplatin & 2.85 & 6.50 & 7.20 & 2.95 & 7.60 & 3.20 \\
\hline
\end{tabular}

${ }^{\mathrm{a}} \mathrm{IC}_{50}$ corresponds to the concentration required to inhibit $50 \%$ of the cell growth when the cells are exposed to the compounds during $48 \mathrm{~h}$. Each value is the average of two independent experiments.

${ }^{\mathrm{b}}$ Lung large cell carcinoma (H460), prostate carcinoma (DU145), breast adenocarcinoma (MCF-7), amelanotic melanoma (M-14), colon adenocarcinoma (HT29), and chronic myelogenous leukemia (K562).

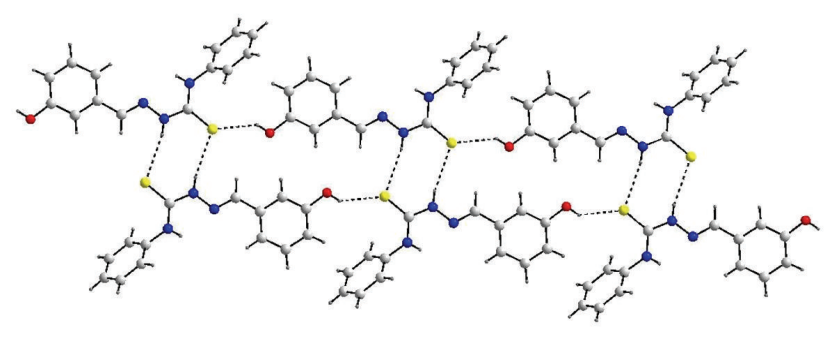

FIGURE 4: Double chain structure of $\operatorname{HTSC}^{3}$ in the crystal.

agreement with the proposed intercalation mechanism as the intercalation is favored for a planar moiety.

Complex $\left[\mathrm{Pd}\left(\mathrm{TSC}^{5}\right)_{2}\right] \quad(\mathbf{1 0})\left(\mathrm{IC}_{50}=0.78 \mu \mathrm{M}\right)$ tested against the MCF-7 tumor cell line resulted to be more cytotoxic than the palladium(II) monochelate complexes with 2-acetylpyridine thiosemicarbazone derivatives $\left(\mathrm{IC}_{50}=\right.$ 4.9-5.5 $\mu \mathrm{M}$ ) when being tested on the MDA-MB231 human breast cancer cell line [32]. Furthermore, complex (10) tested in vitro against the HT29 colon adenocarcinoma tumor cell line exhibited higher cytotoxicity $\left(\mathrm{IC}_{50}=1.04 \mu \mathrm{M}\right)$ than that of the $[\mathrm{Pd}(\operatorname{mpETSC}) \mathrm{Cl}](\mathrm{HmpETSC}=4$-ethyl1-(6' $6^{\prime}$-methylpyridine- $2^{\prime}$-carbaldehyde $)$ thiosemicarbazone) monochelate complex $\left(\mathrm{IC}_{50}=20.65 \mu \mathrm{M}\right)$ assayed on the HCT 116 human colon tumor cell line [26].

In summary, we have synthesized palladium(II) bischelate complexes with ligands derived from acetone, benzaldehyde, and naphthaldehyde thiosemicarbazone. The molecular structure of $\left[\operatorname{Pd}\left(\mathrm{TSC}^{1}\right)_{2}\right](6)$ shows a squareplanar geometry with deprotonated ligands coordinated to $\mathrm{Pd}(\mathrm{II})$ through the azomethine nitrogen and thione sulfur atoms in a cis arrangement.

Of all the studied complexes, the hydroxy-substituted $\left[\operatorname{Pd}\left(\mathrm{TSC}^{3}\right)_{2}\right](8)$ complex resulted to be more cytotoxic in all tumor cell lines at low micromolar concentrations, compared to the other complexes and the free ligands.

3.6. Extra Material. Crystallographic data for the structural analysis have been deposited with the Cambridge Crystallographic Data Centre, numbers CCDC 894930 for HTSC ${ }^{3}$, 894931 for $\left[\operatorname{Pd}\left(\text { TSC }^{1}\right)_{2}\right]$, and 894932 for HTSC $^{4}$. Copies of this information can be obtained free of charge from the 


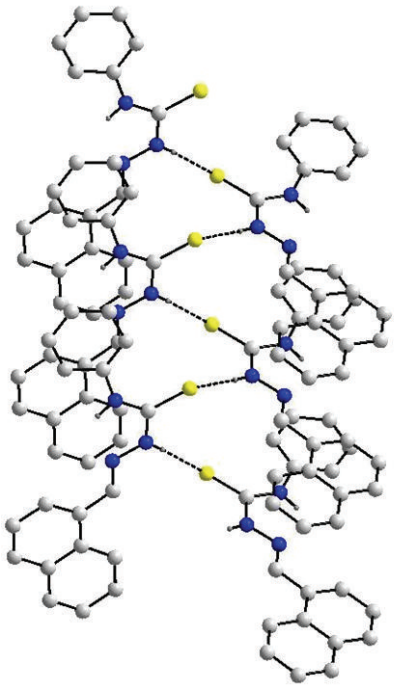

FIGURE 5: Helix structure of $\operatorname{HTSC}^{4}$ in the crystal.

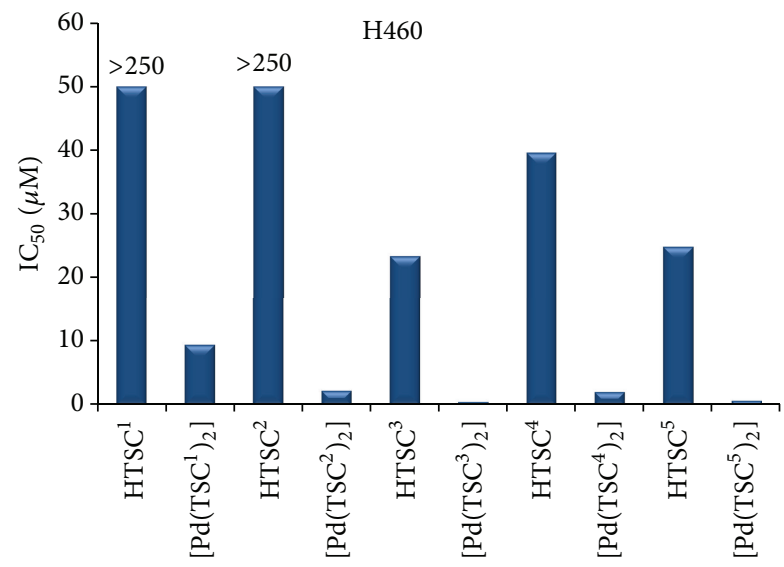

(a)

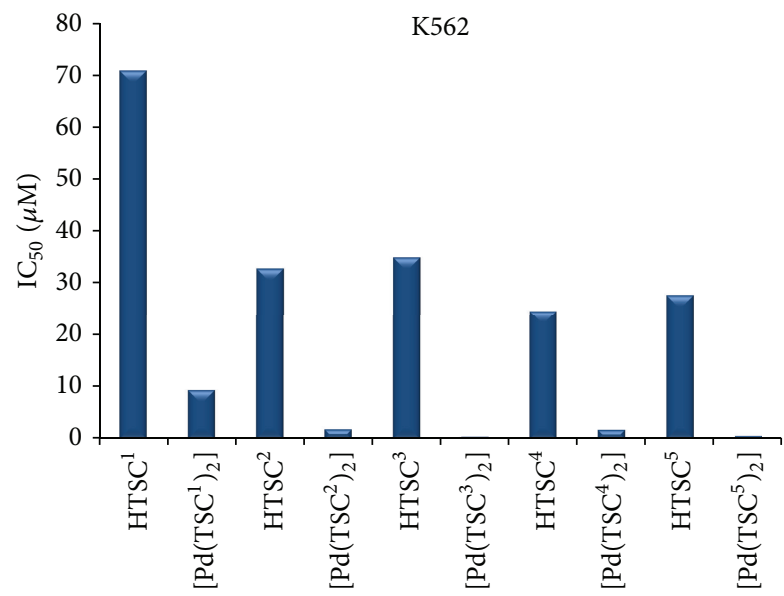

(b)

FIGURE 6: The antiproliferative activity in vitro expressed as $\mathrm{IC}_{50}$ $(\mu \mathrm{M})$ values of the ligands HTSC $^{1-5}$ and palladium(II) complexes $\left[\mathrm{Pd}\left(\mathrm{TSC}^{1-5}\right)_{2}\right]$ against (a) H460 and (b) K562 human tumor cell lines after $48 \mathrm{~h}$ incubation time.

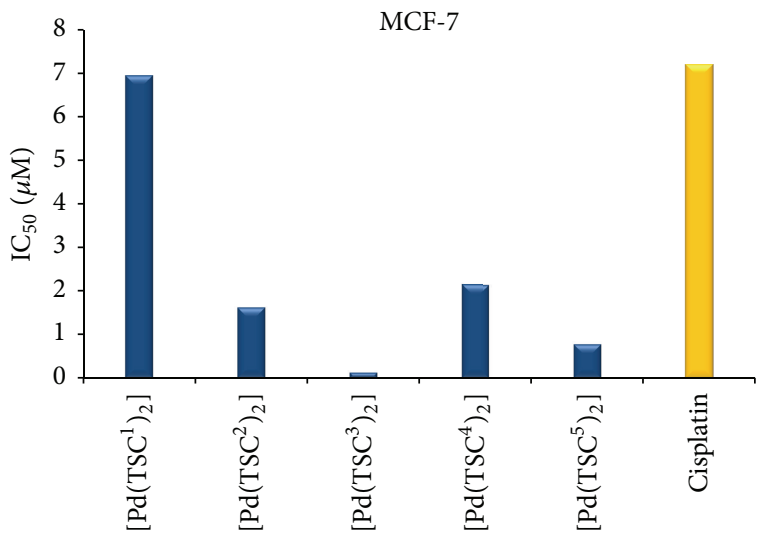

FIGURE 7: The antiproliferative activity in vitro expressed as $\mathrm{IC}_{50}$ $(\mu \mathrm{M})$ values of the ligands $\mathrm{HTSC}^{1-5}$, palladium(II) complexes $\left[\mathrm{Pd}\left(\mathrm{TSC}^{1-5}\right)_{2}\right]$, and cisplatin against MCF-7 human tumor cell line after $48 \mathrm{~h}$ incubation time.

Cambridge Crystallographic Data Center (CCDC, 12 Union Road, Cambridge CB2 1EZ, UK; fax: (+44) 1223-336-033; email: deposit@ccdc.cam.ac.uk).

\section{Acknowledgments}

Wilfredo Hernández gratefully thanks the Universidad de Lima Scientific Research Institute for financial support to carry out the research work. The authors also thank the Development and Research Laboratory of the Faculty of Sciences and Philosophy, Universidad Peruana Cayetano Heredia, for the evaluation of the cytotoxic activity of the compounds. Evgenia Spodine and Jorge Manzur thank Financiamiento Basal Program, FB0807 Project (CEDENNA).

\section{References}

[1] G. Pelosi, F. Bisceglie, F. Bignami et al., "Antiretroviral activity of thiosemicarbazone metal complexes," Journal of Medicinal Chemistry, vol. 53, no. 24, pp. 8765-8769, 2010.

[2] A. Karaküçük-Iyidoğan, D. Taşdemir, E. E. Oruç-Emre, and J. Balzarini, "Novel platinum(II) and palladium(II) complexes of thiosemicarbazones derived from 5-substitutedthiophene-2carboxaldehydes and their antiviral and cytotoxic activities," European Journal of Medicinal Chemistry, vol. 46, no. 11, pp. 5616-5624, 2011.

[3] P. Genova, T. Varadinova, A. I. Matesanz, D. Marinova, and P. Souza, "Toxic effects of bis(thiosemicarbazone) compounds and its palladium(II) complexes on herpes simplex virus growth," Toxicology and Applied Pharmacology, vol. 197, no. 2, pp. 107-112, 2004.

[4] S. Thota, S. S. Karki, and B. R. Bhukya, "Synthesis, characterization and antibacterial activity of some novel mononuclear $\mathrm{Ru}(\mathrm{II})$ complexes," International Journal of Pharmacy and Pharmaceutical Sciences, vol. 1, no. 2, pp. 62-70, 2009.

[5] I. Kizilcikh, Y. D. Kurt, B. A. kkurt et al., "Antimicrobial activity of a series of thiosemicarbazones and their $\mathrm{Zn}^{\mathrm{II}}$ and $\mathrm{Pd}^{\mathrm{II}}$ Complexes," Folia Microbiologica, vol. 52, pp. 15-25, 2007.

[6] T. Rosu, A. Gulea, A. Nicolae, and R. Georgescu, "Complexes of $3 \mathrm{dn}$ metal ions with thiosemicarbazones: synthesis and 
antimicrobial activity," Molecules, vol. 12, no. 4, pp. 782-796, 2007.

[7] M. Er, Y. Ünver, K. Sancak, and E. Dügdü, "Synthesis and characterizations of some new tetra-thiosemicarbazones and their cyclization reactions; tetra-4-methyl-5-etoxycarbonyl2,3-dihydro-1,3- thiazole and tetra-2-acetylamino-4-acetyl-4,5dihydro-1,3,4-thiodiazole derivatives," Arkivoc, vol. 15, pp. 99120, 2008.

[8] S. Chandra and M. Tyagi, "Ni(II), Pd(II) and Pt(II) complexes with ligand containing thiosemicarbazone and semicarbazone moiety: synthesis, characterization and biological investigation," Journal of the Serbian Chemical Society, vol. 73, no. 7, pp. 727-734, 2008.

[9] S. S. Konstantinović, B. C. Radovanović, S. P. Sovilj, and S. Stanojević, "Antimicrobial activity of some isatin-3thiosemicarbazone complexes," Journal of the Serbian Chemical Society, vol. 73, no. 1, pp. 7-13, 2008.

[10] R. V. Singh, N. Fahmi, and M. K. Biyala, "Coordination behavior and biopotency of $\mathrm{N}$ and $\mathrm{S} / \mathrm{O}$ donor ligands with their palladium(II) and platinum(II) complexes," Journal of the Iranian Chemical Society, vol. 2, pp. 40-46, 2005.

[11] L. Otero, M. Vieites, L. Boiani et al., "Novel antitrypanosomal agents based on palladium nitrofurylthiosemicarbazone complexes: DNA and redox metabolism as potential therapeutic targets," Journal of Medicinal Chemistry, vol. 49, no. 11, pp. 33223331, 2006.

[12] P. Chellan, T. Stringer, A. Shokar et al., "Synthesis and in vitro evaluation of palladium(II) salicylaldiminato thiosemicarbazone complexes against Trichomonas vaginalis," Journal of Inorganic Biochemistry, vol. 105, no. 12, pp. 1562-1568, 2011.

[13] N. A. Lewis, F. Liu, L. Seymour et al., "Synthesis, characterisation, and preliminary in vitro studies of vanadium(IV) complexes with a Schiff base and thiosemicarbazones as mixed ligands," European Journal of Inorganic Chemistry, no. 4, pp. 664-677, 2012.

[14] E. Ramachandran, P. Kalaivani, R. Prabhakaran et al., "Synthesis, X-ray crystal structure, DNA binding, antioxidant and cytotoxicity studies of $\mathrm{Ni}(\mathrm{II})$ and $\mathrm{Pd}(\mathrm{II})$ thiosemicarbazone complexes," Metallomics, vol. 4, no. 2, pp. 218-227, 2012.

[15] U. Kulandaivelu, V. G. Padmini, K. Suneetha et al., "Synthesis, antimicrobial and anticancer activity of new thiosemicarbazone derivatives," Archiv der Pharmazie, vol. 344, no. 2, pp. 84-90, 2011.

[16] B. Atasever, B. Ülküseven, T. Bal-Demirci, S. Erdem-Kuruca, and Z. Solakoǧlu, "Cytotoxic activities of new iron(III) and nickel(II) chelates of some S-methyl-thiosemicarbazones on K562 and ECV304 cells," Investigational New Drugs, vol. 28, no. 4, pp. 421-432, 2010

[17] M. X. Li, C. L. Chen, D. Zhang, J. Y. Niu, and B. S. Ji, "Mn(II), $\mathrm{Co}(\mathrm{II})$ and $\mathrm{Zn}(\mathrm{II})$ complexes with heterocyclic substituted thiosemicarbazones: synthesis, characterization, X-ray crystal structures and antitumor comparison," European Journal of Medicinal Chemistry, vol. 45, no. 7, pp. 3169-3177, 2010.

[18] V. Vrdoljak, I. Dilović, M. Rubčić et al., "Synthesis and characterisation of thiosemicarbazonato molybdenum(VI) complexes and their in vitro antitumor activity," European Journal of Medicinal Chemistry, vol. 45, pp. 38-48, 2010.

[19] K. S. O. Ferraz, L. Ferandes, D. Carrilho et al., "2Benzoylpyridine-N(4)-tolyl thiosemicarbazones and their palladium(II) complexes: cytotoxicity against leukemia cells," Bioorganic and Medicinal Chemistry, vol. 17, no. 20, pp. 7138-7144, 2009.
[20] H. Khan, A. Badshah, Z.-U. Zia-Ur-Rehman et al., "New dimeric and supramolecular mixed ligand Palladium(II) dithiocarbamates as potent DNA binders," Polyhedron, vol. 39, no. 1, pp. 1-8, 2012.

[21] H. Khan, A. Badshah, G. Murtaz et al., "Synthesis, characterization and anticancer studies of mixed ligand dithiocarbamate palladium(II) complexes," European Journal of Medicinal Chemistry, vol. 46, no. 9, pp. 4071-4077, 2011.

[22] T. S. Lobana, R. Sharma, G. Bawa, and S. Khanna, "Bonding and structure trends of thiosemicarbazone derivatives of metals-An overview," Coordination Chemistry Reviews, vol. 253, no. 7-8, pp. 977-1055, 2009.

[23] L. N. Suvarapu, A. V. Reddy, G. S. Kumar, and S. Ok Baek, "Spectral characterization and antibacterial activities of benzyloxybenzaldehydethiosemicarbazone 3,4-dihydroxybenzaldehydeisonicotinoylhydrazone and their transitional metal complexes," European Journal of Chemistry, vol. 8, no. 4, pp. 18481858, 2011.

[24] S. Thota, S. S. Karki, K. N. Jayaveera, J. Balzarini, and E. D. Clercq, "Synthesis and cytotoxic activity of some mononuclear $\mathrm{Ru}(\mathrm{II})$ Complexes," Research Journal of Pharmaceutical, Biological and Chemical Sciences, vol. 1, no. 3, pp. 704-713, 2010.

[25] N. Sampath, M. N. Ponnuswamy, and M. Nethaji, "Crystal structure and conformation study of N-methyl-t-3-methylr-2, c-6-diphenylpiperidin-4-one thiosemicarbazone," Crystal Research and Technology, vol. 41, no. 2, pp. 192-197, 2006.

[26] I. S. Butler, S. A. Elsayed, A. M. El-Hendawy, S. I. Mostafa, B. J. Jean-Claude, and M. Todorova, "Antineoplastic activity of new transition metal complexes of 6-methylpyridine-2carbaldehyde-n(4)-ethylthiosemicarbazone: X-Ray crystal structures of [VO2(mpETSC)] and [Pt(mpETSC)Cl]," Bioinorganic Chemistry and Applications, vol. 2010, Article ID 149149, 11 pages, 2010.

[27] W. Hernándeza, J. Paz, A. Vaisberg, E. Spodine, R. Richter, and L. Beyer, "Synthesis, characterization, and in vitro cytotoxic activities of benzaldehyde thiosemicarbazone derivatives and their palladium (II) and platinum (II) complexes against various human tumor cell lines," Bioinorganic Chemistry and Applications, vol. 2008, Article ID 690952, 9 pages, 2008.

[28] L. J. Farrugia, "WinGX suite for small-molecule single-crystal crystallography," Journal of Applied Crystallography, vol. 32, no. 4, pp. 837-838, 1999.

[29] G. M. Sheldrick, "A short history of SHELX," Acta Crystallographica A, vol. 64, no. 1, pp. 112-122, 2007.

[30] P. Skehan, R. Storeng, D. Scudiero et al., "New colorimetric cytotoxicity assay for anticancer-drug screening," Journal of the National Cancer Institute, vol. 82, no. 13, pp. 1107-1112, 1990.

[31] B. Glinma, D. S. S. Kpoviessi, F. A. Gbaguidi et al., "Synthesis, caracterization, trypanosomal activities on Trypanosoma bruceibrucei and toxicity against Artemia salina leach of N(4)-aryl semicarbazones and thiosemicarbazones," Journal of Chemical and Pharmaceutical Research, vol. 4, no. 2, pp. 1016-1021, 2012.

[32] P. I. S. da Maia, A. Graminha, F. R. Pavan et al., "Palladium(II) complexes with thiosemicarbazones: syntheses, characterization and cytotoxicity against breast cancer cells and antiMycobacterium tuberculosis activity," Journal of the Brazilian Chemical Society, vol. 21, no. 7, pp. 1177-1186, 2010.

[33] T. S. Lobana, A. Sánchez, J. S. Casas et al., "Symmetrisation, isomerism and structural studies on novel phenylmercury(II) thiosemicarbazonates: correlation of the energy barrier to rotation of the amino group with the bonding parameters of 
the thioamide group," Journal of the Chemical Society, no. 22, pp. 4289-4299, 1997.

[34] R. M. El-Shazly, G. A. A. Al-Hazmi, S. E. Ghazy, M. S. ElShahawi, and A. A. El-Asmy, "Synthesis and spectroscopic characterization of cobalt(II) thiosemicarbazone complexes," Journal of Coordination Chemistry, vol. 59, no. 8, pp. 845-859, 2006.

[35] R. K. Agarwal, L. Singh, and D. K. Sharma, "Synthesis, spectral, and biological properties of copper(II) complexes of thiosemicarbazones of Schiff bases derived from 4-aminoantipyrine and aromatic aldehydes," Bioinorganic Chemistry and Applications, vol. 2006, Article ID 59509, 10 pages, 2006.

[36] O. P. Pandey, S. K. Sengupta, M. K. Mishra, and C. M. Tripathi, "Synthesis, spectral and antibacterial studies of binuclear titanium(IV)/zirconium(IV) complexes of piperazine dithiosemicarbazones," Bioinorganic Chemistry and Applications, vol. 1, no. 1, pp. 35-44, 2003.

[37] A. A. El-Asmy, M. E. Khalifa, and M. M. Hassanian, "Synthesis of mono and binuclear complexes of $\alpha$-oximinoacetoacetanilide-4-phenylthiosemicarbazone," Synthesis and Reactivity in Inorganic and Metal-Organic Chemistry, vol. 31, no. 10, pp. 17871801, 2001.

[38] A. S. A. Zidan and A. I. El-Said, "Studies of mixed ligand complexes from dialkyldithiophosphate and thiosemicarbazide or thiosemicarbazones with nickel(II)," Phosphorus, Sulfur and Silicon and the Related Elements, vol. 179, no. 7, pp. 1293-1305, 2004.

[39] M. A. Affan, F. S. Wan, Z. Ngaini, and M. Shamsuddin, "Synthesis, characterization and biological studies of organotin(IV) complexes of thiosemicarbazone ligand derived from pyruvic acid: X-ray crystal structure of [Me2Sn(PAT)]," The Malaysian Journal of Analytical Sciences, vol. 13, pp. 63-72, 2009.

[40] F. Yakuphanoglu, A. Balaban, F. Dagdelen, Y. Aydogdu, M. Sekerci, and B. Erk, "Synthesis, characterization, and electrical properties of metal complexes of 2-pyridinecarbaldehyde thiosemicarbazone," Synthesis and Reactivity in Inorganic and Metal-Organic Chemistry, vol. 32, no. 10, pp. 1865-1878, 2002.

[41] G. Rajendran, C. S. Amritha, R. J. Anto, and V. T. Cheriyan, "Synthesis, thermal and antitumour studies of Th(IV) complexes with furan-2-carboxaldehyde4-phenyl-3thiosemicarbazone," Journal of the Serbian Chemical Society, vol. 75, no. 6, pp. 749-761, 2010.

[42] W. Hernández, J. Paz, F. Carrasco et al., "Synthesis and characterization of new palladium(II) complexes with ligands derived from furan-2-carbaldehyde and benzaldehyde thiosemicarbazone and their in vitro cytotoxic activities against various human tumor cell lines," Zeitschrift für Naturforschung B, vol. 65, no. 10, pp. 1271-1278, 2010.

[43] A. P. Kumar, P. R. Reddy, and V. K. Reddy, "Spectrophotometric determination of nickel(II) with 2-hydroxy-3-methoxybenzaldehyde thiosemicarbazone," Indian Journal of Chemistry A, vol. 46, no. 10, pp. 1625-1629, 2007.

[44] T. Stringer, P. Chellan, B. Therrien, N. Shunmoogam-Gounden, D. T. Hendricks, and G. S. Smith, "Synthesis and structural characterization of binuclear palladium(II) complexes of salicylaldimine dithiosemicarbazones," Polyhedron, vol. 28, no. 14, pp. 2839-2846, 2009.

[45] I. Kizilcikli, B. Ülküseven, Y. Daşdemir, and B. Akkurt, "Zn(II) and $\mathrm{Pd}(\mathrm{II})$ complexes of thiosemicarbazone-S-alkyl esters derived from 2/3-formylpyridine," Synthesis and Reactivity in Inorganic and Metal-Organic Chemistry, vol. 34, no. 4, pp. 653665, 2004.
[46] A. A. Al-Amiery, Y. K. Al-Majedy, H. Abdulreazak, and H. Abood, "Synthesis, characterization, theoretical crystal structure, and antibacterial activities of some transition metal complexes of the thiosemicarbazone (Z)-2-(pyrrolidin-2ylidene)hydrazinecarbothioamide," Bioinorganic Chemistry and Applications, vol. 2011, Article ID 483101, 6 pages, 2011.

[47] D. Kovala-Demertzi, J. Wiecek, Z. Ciunik, M. Zervou, and M. A. Demertzis, "Diorganotin complexes of a thiosemicarbazone, synthesis: properties, X-ray crystal structure, and antiproliferative activity of diorganotin complexes," Bioinorganic Chemistry and Applications, vol. 2010, Article ID 867195, 9 pages, 2010.

[48] T. A. Yousef, F. A. Badria, S. E. Ghazy, O. A. El-Gammal, and G. M. A. El-Reash, "In vitro and in vivo antitumor activity of some synthesized 4-(2-pyridyl)-3-thiosemicarbazides derivatives," International Journal of Medicine and Medical Sciences, vol. 3, pp. 37-46, 2011.

[49] J. A. Lessa, J. C. Guerra, L. F. De Miranda et al., "Gold(I) complexes with thiosemicarbazones: cytotoxicity against human tumor cell lines and inhibition of thioredoxin reductase activity," Journal of Inorganic Biochemistry, vol. 105, no. 12, pp. 17291739, 2011. 

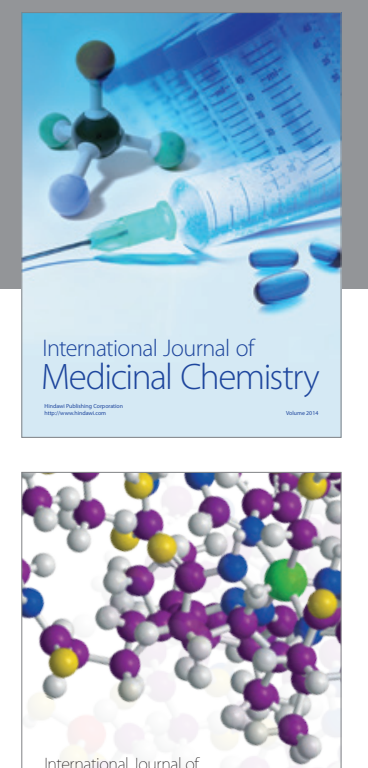

\section{Carbohydrate} Chemistry

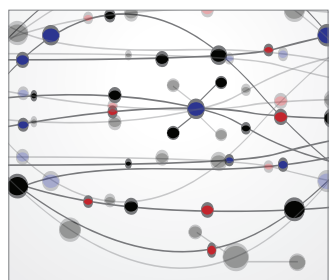

The Scientific World Journal
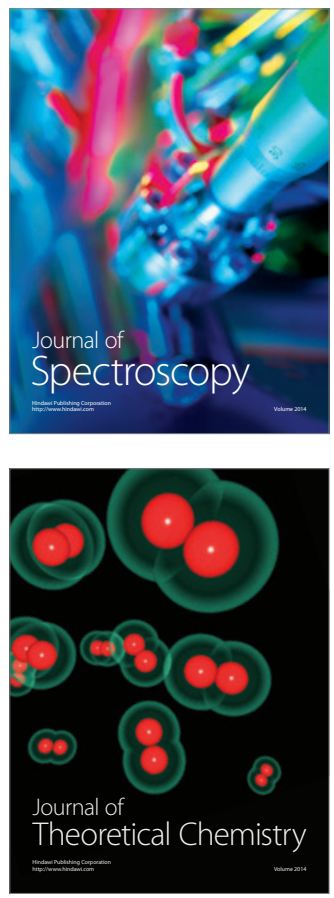
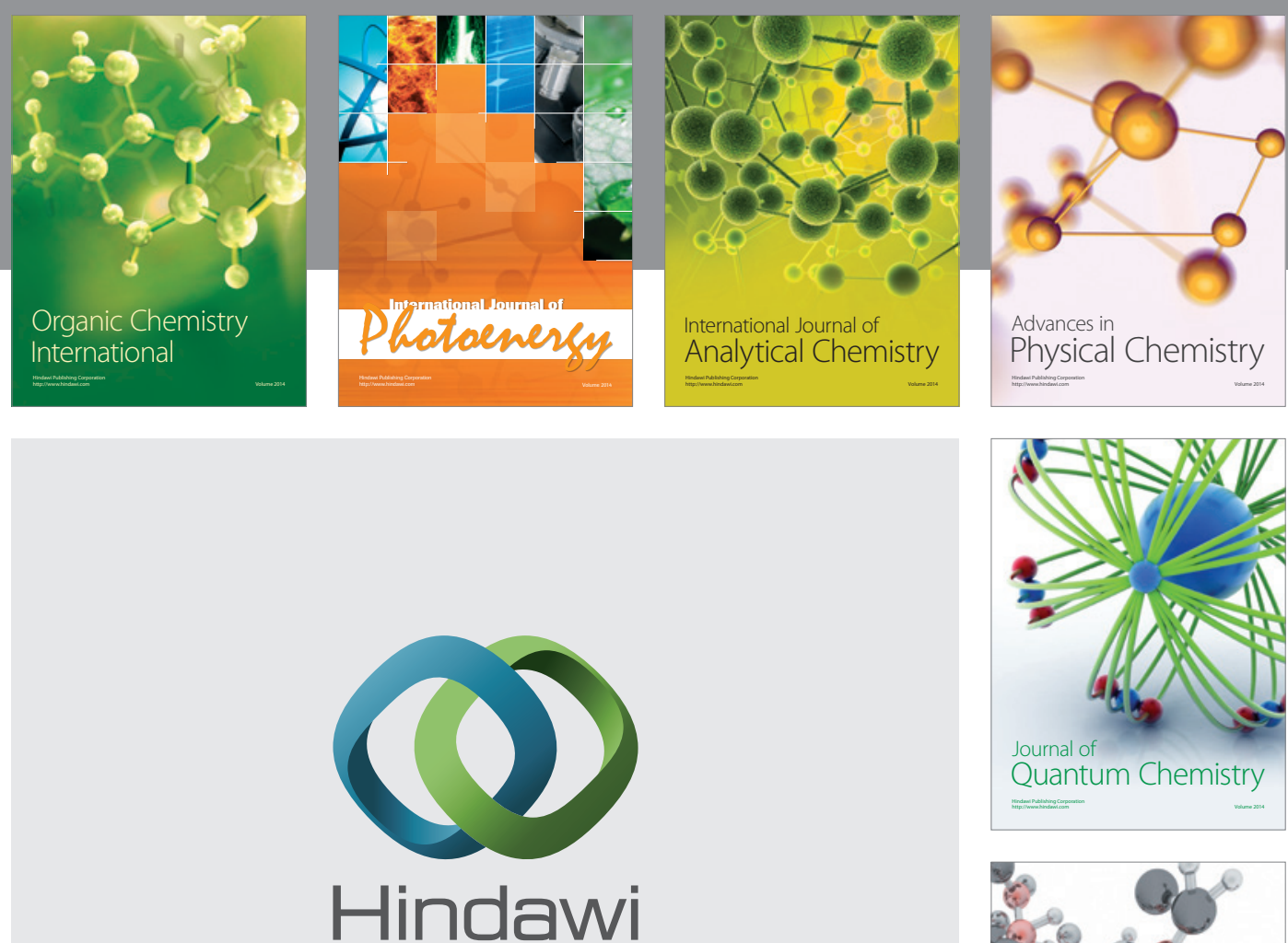

Submit your manuscripts at

http://www.hindawi.com

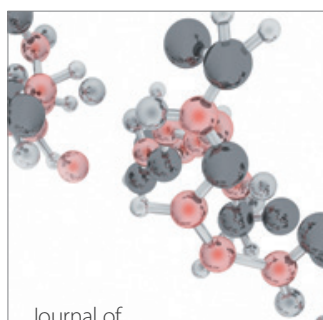

Analytical Methods

in Chemistry

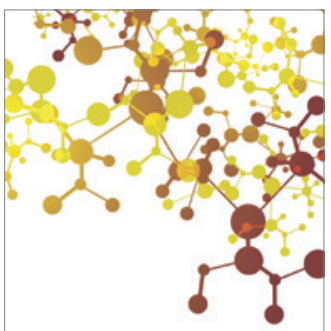

Journal of

Applied Chemistry

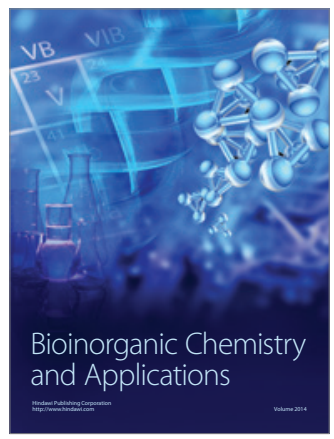

Inorganic Chemistry
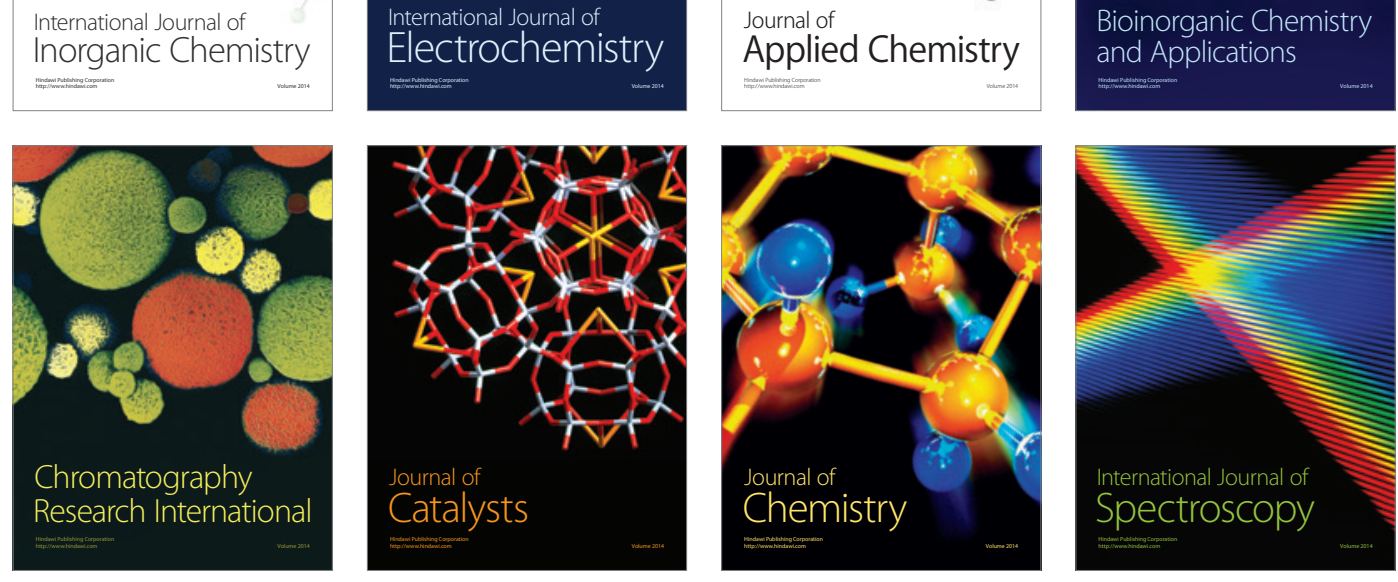